This article can be cited as: Rabat, Á., Cano, M., Tomás, R. (2020). Effect of water saturation on strength and deformability of building calcarenite stones: Correlations with their physical properties. Construction and Building Materials, 232, 117259.

https://doi.org/10.1016/j.conbuildmat.2019.117259

\title{
EFFECT OF WATER SATURATION ON STRENGTH AND DEFORMABILITY OF BUILDING CALCARENITE STONES: CORRELATIONS WITH THEIR PHYSICAL PROPERTIES
}

\author{
Á. Rabat ${ }^{\mathrm{a} *}$, M. Cano ${ }^{\mathrm{a}}$, R. Tomás ${ }^{\mathrm{a}}$
}

a Departamento de Ingeniería Civil, Escuela Politécnica Superior, Universidad de Alicante, P.O. Box 99, E-03080 Alicante, Spain

* Corresponding author. alvaro.rabat@ua.es

\section{ABSTRACT}

Stone construction elements are frequently in moist environments or in direct contact with water. Design and test standards have traditionally ignored the water impact on rock materials. However, several studies have shown that moisture can cause drastic strength reductions and deformability increase in some sedimentary rocks. For that reason, the main objectives of this work are: a) to quantify and understand the influence of water saturation on strength and deformability of four porous calcarenite building stones widely used in SE Spain ; b) to establish correlations between physical and mechanical properties of these rock materials in dry and saturated states and c) to compare the results with previous findings. The results showed a very significant reduction of mechanical properties such as unconfined compressive strength, Young's modulus and point load strength index when these stones undergo saturated. In addition, significant correlations between physical properties (density, porosity, P wave velocity and dynamic elastic parameters) and the mentioned mechanical properties were established in dry and saturated conditions. Additionally, relationships among the mechanical properties of stones in both states are also proposed.

Keywords: calcarenite, building stones, water saturation, physical properties, mechanical properties

\section{List of symbols}

$\rho_{\mathrm{b}}$ : bulk density

$\rho_{\mathrm{d}}$ : dry density

$\rho_{\text {sat: }}$ saturated density

$\gamma_{d}$ : dry specific weight

$\gamma_{\text {sat: }}$ saturated specific weight

$p_{0}$ : open porosity

p: total porosity

$\mathrm{W}_{\mathrm{a}}$ : water absorption

UCS: Unconfined Compressive Strength

$E_{\text {st: }}$ Static Young's modulus

$I_{s(50)}$ : Point Load Strength Index

$\mathrm{V}_{\mathrm{p}}$ : P-wave velocity

$\mathrm{V}_{\mathrm{s}}$ : S-wave velocity

$E_{\text {dyn }}$ : Dynamic Young's modulus

$v_{\text {dyn }}$ : Dynamic Poisson's coefficient 
$\mathrm{d}$ : Pore diameter

$\chi$ : mean value

$\sigma:$ standard deviation

PLT: Point load test

$r^{2}$ : Coefficient of determination

\section{INTRODUCTION}

Durability is an important engineering parameter, particularly for the conservation of stone heritage buildings, that is currently a topic in vogue. In this context, many researches have studied the influence of mineralogical and petrological properties on calcarenite stones weathering and demonstrated that even when short-term behaviour is acceptable, the atmospheric conditions affect them in long-term causing granular disintegration and fissures [1]. Concretely, calcarenite stones durability differs depending on the agents of decay. On the whole, humidity variations induced by temperature changes can weaken the stone more than freezethaw and salt crystallisation cycles [2].

Several authors have also studied the influence of moisture on unconfined compressive strength of sedimentary rocks, but nevertheless the water impact on other mechanical and physical properties have been less explored, especially for calcarenite building stones. In this context, it should be recalled that many civil engineering works and architectural buildings constructed with these rock types are usually outdoors or in direct contact with water (e.g. singular buildings, retaining systems, ornamental elements, bridges, foundations or harbours). In addition, in many practical situations, it is absolutely crucial for safety reasons to consider the saturation effect on strength and deformability of rock materials as in dams foundations, rockfills or structures placed in areas affected by high or significant water level table variations [3].

Specifically, this study focused on the evaluation of the effect of water saturation on strength and deformability of four calcarenite stones from the SE Spain: three commercial varieties of an ornamental calcarenite stone known as Blue, Beige and Diamond Bateig, and one yellow finegrained calcarenite utilised in civil works.

Blue, Beige and Diamond calcarenites have been widely used within the architectural heritage of SE Spain. For example, Novelda Modernist Museum and Valencia City Hall have facades in a combination of Bateig Beige and Bateig Diamond. Furthermore, others Spanish emblematic building like Madrid City Hall, the Bank of Spain headquarters or the Monument to Alfonso XII in Madrid were built with Bateig stones [2], [4]. At present, these rocks are used in building facades, decorative features, masonry walls or as substitution material for the restauration of architectural heritage. Concerning the yellow fine-grained calcarenite it is principally used in civil engineering elements like rockfills, retaining systems, rock embankments, protection walls or foundations (Fig. 1). 


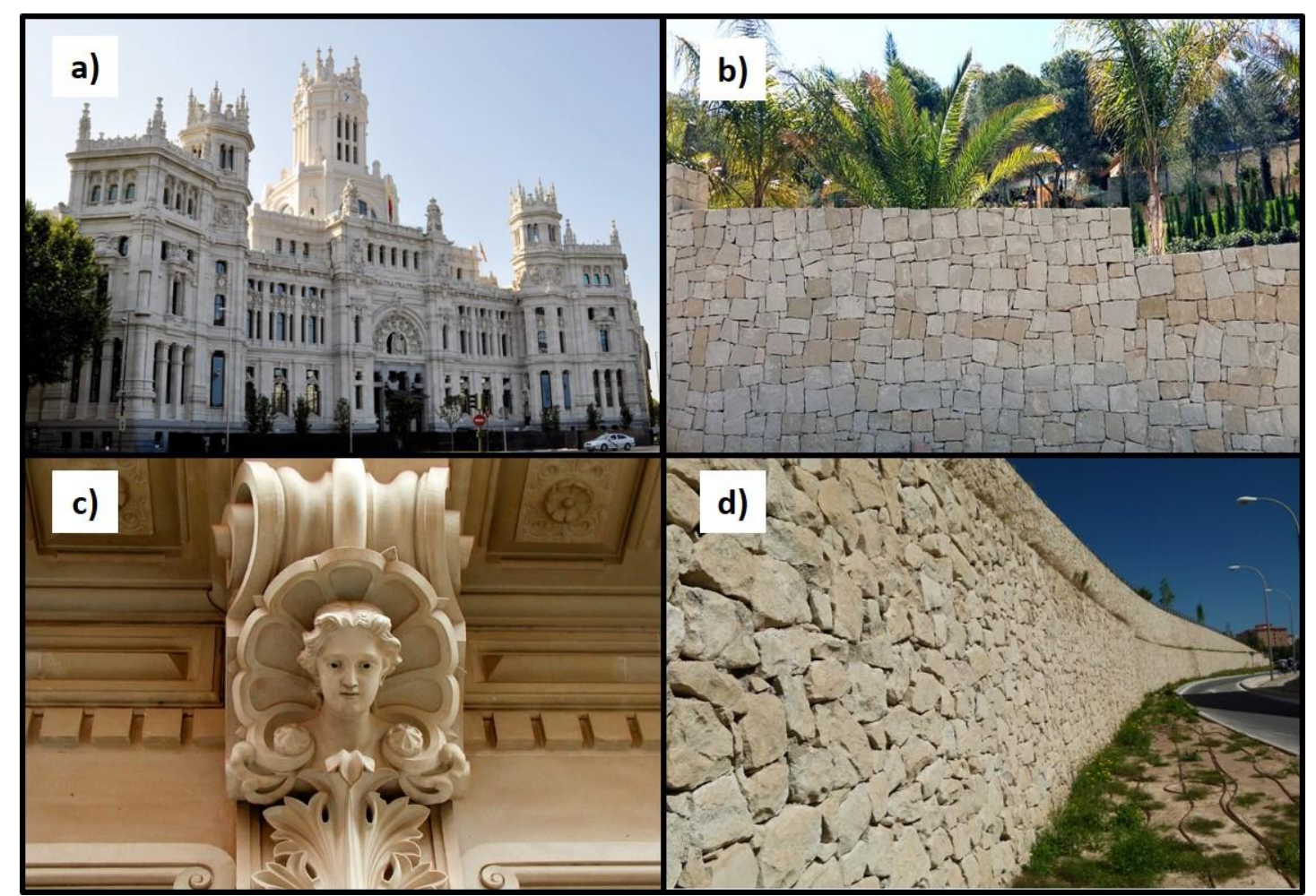

Fig. 1. Different uses of the calcarenite stones studied in this work: a) Madrid City Hall facade built with Beige variety; b) Natural Masonry built with Blue, Beige and Diamond varieties; c) Ornamental element built with Diamond variety; d) Rock retainig wall

built with yellow variety.

Previous studies have shown that moisture plays a key role in the strength of some sedimentary rocks. Concerning sandstones behaviour, Price [5] observed that the unconfined compressive strength (UCS) of saturated samples was $45 \%$ lower than that of oven-dried samples. Mann and Fatt [6] found that the Young's modulus $\left(E_{s t}\right)$ value of three types of saturated sandstones was $8-20 \%$ less than for dry due to its high clay content. Also Colback and Wiid [7] observed that the UCS of quartzitic shales and sandstones decreased following a linear trend when wetted in fluids of increasing surface tension because of the loss of free energy of quartz. Furthermore, Shakoor and Barefield [8] obtained strength reductions of up to $71.6 \%$ between dry and saturated states and significant trends of UCS reduction with increasing moisture content in sandstones from Ohio. Furthermore, three types of ferruginous sandstones were tested by Verstringe et al. [9] under dry and saturated conditions. Their results showed a decrease of up to 40,50 and $59 \%$ for each variety due to water saturation and concluded that pore and grain size distribution and clay content were key elements in this strength reduction.

With regards to limestones, Vásárhelyi [10] analysed data obtained from UCS and $E_{\text {st }}$ under dry and saturated conditions for 45 Miocene limestone blocks and statistically obtained mean reductions of 34.1 and $34.3 \%$ on these mechanical properties. Torok and Vásárhelyi [11] studied two types of travertines in both states and found that UCS decreased up to $11 \%$ and P-wave velocity increased up to $7 \%$ due to water saturation. A compilation of the ratios $(K)$ between saturated and dry values of some physical and mechanical properties of several rock types found in previous studies is shown in Table 1. 
Table 1. Ratios (K) between saturated and dry values of some physical and mechanical properties of several rock materials found in scientific literature. $V_{p}$ : P-wave velocity; UCS: Unconfined compressive strength; $E_{s t}$ : Static Young's modulus; $I_{s(50)}$ : Point Load Strength Index.

\begin{tabular}{|c|c|c|c|}
\hline Authors & \multicolumn{2}{|c|}{$\begin{array}{c}\text { Ratio between saturated and dry values of } \\
\text { physical and mechanical properties (K) }\end{array}$} & Rock type \\
\hline Torok and Vásárhelyi (2010) [11] & \multirow{9}{*}{$K_{v_{p}}=\frac{V_{p-s a t}}{V_{p-d r y}}$} & 1.07 & Travertines \\
\hline \multirow{5}{*}{ Karakul and Ulusay (2013) [12] } & & 1.20 & Turkish sandstones \\
\hline & & 1.05 & Turkish andesites \\
\hline & & 0.99 & Turkish argillaceous limestones \\
\hline & & 0.72 & Turkish marls \\
\hline & & 0.77 & Turkish Ignimbrite \\
\hline \multirow{3}{*}{ Kahraman (2007) [13] } & & 1.34 & Turkish travertines \\
\hline & & 1.29 & Turkish limestones \\
\hline & & 1.31 & Turkish sandstones \\
\hline Vásárhelyi (2005) [10] & \multirow{6}{*}{$K_{U C S}=\frac{U C S_{\text {sat }}}{U C S_{d r y}}$} & 0.66 & Miocene limestones \\
\hline Torok and Vásárhelyi (2010) [11] & & 0.89 & Travertines \\
\hline Gájic et al. (2011) [14] & & 0.92 & Struganik limestone \\
\hline Shakoor and Barefield (2009) [8] & & 0.28 & American sandstones \\
\hline Verstrynge et al. (2014) [9] & & 0.50 & Ferruginous sandstones \\
\hline Lin et al. (2005) [15] & & 0.47 & Tertiary sandstones \\
\hline Vásárhelyi (2005) [10] & \multirow{4}{*}{$K_{E_{s t}}=\frac{E_{s t-s a t}}{E_{s t-d r y}}$} & 0.65 & Miocene limestones \\
\hline Kim and Changani (2016) [16] & & 0.92 & Red and Buff sandstones \\
\hline Karakul and Ulusay (2013) [12] & & 0.35 & Several Turkish rocks \\
\hline Hawkins and McConell (1992) [17] & & 0.79 & British sandstones \\
\hline Broch (1983) [18] & \multirow{3}{*}{$K_{I S(50)}=\frac{I_{s(50) s a t}}{I_{s(50) d r y}}$} & 0.85 & Several rock types \\
\hline Kohno and Maeda (2012) & & 0.41 & Volcaniclastic rocks \\
\hline Kahraman (2014) [19] & & 0.65 & Pyroclastic rocks \\
\hline
\end{tabular}

Another aspect to be noted is that most of the standards to determine mechanical properties of rocks specify regulations as diameter and slenderness of the samples, minimum number of specimens or speed of load application, but almost none of them define the moisture content of the samples [3]. This mean that most laboratory tests to obtain strength parameters are carried out under dry rock samples, despite the fact that in engineering practice rock masses are frequently under non-dry environments [20]. Therefore, obtaining correlation functions between physical and mechanical properties of rock materials in dry and water saturated conditions is necessary to predict the behaviour and durability of rock materials and optimising the election the most appropriated rock type when it is expected that they were subjected to wet or saturated environments during its lifetime. In this line, it must be underlined that few studies have stablished relationships among physical and mechanical parameters in dry and saturated states for sedimentary rock building materials. A compilation of the most relevant correlations is shown in Table 2.

Furthermore, although lot of studies have proposed correlations between Point Load Strength Index $\left(I_{s(50)}\right)$ and UCS [19], a limited number of works have defined these relationships for both moisture states in soft rocks. Similarly, few studies have proposed correlations between $\mathrm{I}_{s(50)}$ and $E_{s t}$. Specifically, Dauod et al. [21] found a power correlation function between both parameters for Iraqi sedimentary rocks. In this line, it is important to note that Point Load Test (PLT) is an alternative indirect method to obtain UCS and $\mathrm{E}_{\text {st }}$ which has some strong points as its simplicity, flexibility in terms of the specimen's shape and size, low cost and the possibility of being performed in the laboratory or in the field. Therefore, this study also tries to close these gaps for the calcarenites. 
Table 2. Equations correlating the UCS, $E_{s t}$ or $I_{s(50)}$ with the physical properties of dry and saturated rock materials found in previous studies. $\rho_{d}$ : dry density; $\rho_{\text {sat: }}$ saturated density; $\gamma_{d}$ : dry specific weight; $\gamma_{\text {sat: }}$ saturated specific weight; $p_{0}$ : open porosity; $p$ : total porosity; $\mathrm{V}_{\mathrm{p}}$ : P-wave velocity; $\mathrm{E}_{\text {dyn }}$ : Dynamic Young's modulus; UCS: Unconfined compressive strength; $\mathrm{E}_{\mathrm{st}}$ : Static Young's modulus;

\begin{tabular}{|c|c|c|c|c|c|}
\hline \multirow[b]{2}{*}{ Authors } & \multirow{2}{*}{$\begin{array}{l}\text { moisture } \\
\text { state of rock }\end{array}$} & \multirow[b]{2}{*}{ Correlation functions } & \multicolumn{2}{|r|}{ Units } & \multirow[b]{2}{*}{ Rock type } \\
\hline & & & $\begin{array}{l}\text { UCS, } E_{s t} \\
\text { or } I_{s(50)}\end{array}$ & Physical property & \\
\hline \multicolumn{6}{|c|}{ Relationships between physical properties and the UCS } \\
\hline \multirow{6}{*}{$\begin{array}{l}\text { Torok and Vásárhelyi } \\
\text { (2010) [11] }\end{array}$} & \multirow{3}{*}{ Dry } & $\mathrm{UCS}=0.0063 \cdot \mathrm{e}^{3.8137 \rho_{\mathrm{d}}}$ & $\mathrm{MPa}$ & $\mathrm{g} / \mathrm{cm}^{3}$ & \multirow{6}{*}{ Travertines } \\
\hline & & $\mathrm{UCS}=204.37 \cdot p_{o}^{-0.6999}$ & $\mathrm{MPa}$ & $\%$ & \\
\hline & & $\mathrm{UCS}=0.5474 \cdot \mathrm{V}_{p}^{3.1088}$ & $\mathrm{MPa}$ & $\mathrm{km} / \mathrm{s}$ & \\
\hline & \multirow{3}{*}{ Saturated } & $\mathrm{UCS}=0.0001 \cdot \mathrm{e}^{5.2435 \rho_{\text {sat }}}$ & $\mathrm{MPa}$ & $\mathrm{g} / \mathrm{cm}^{3}$ & \\
\hline & & $\mathrm{UCS}=193.82 \cdot p_{o}^{-0.7475}$ & $\mathrm{MPa}$ & $\%$ & \\
\hline & & $\mathrm{UCS}=0.0208 \cdot \mathrm{V}_{p}^{4.8916}$ & $\mathrm{MPa}$ & $\mathrm{km} / \mathrm{s}$ & \\
\hline \multirow{4}{*}{ Kim et al. (2017) [16] } & \multirow{2}{*}{ Dry } & $\mathrm{UCS}=0.5 \cdot \mathrm{e}^{2.39 \rho_{d}}$ & $\mathrm{MPa}$ & $\mathrm{g} / \mathrm{cm}^{3}$ & \multirow{4}{*}{ Sandstones } \\
\hline & & $\mathrm{UCS}=259.12 \cdot \mathrm{e}^{-0.06 \mathrm{p}}$ & $\mathrm{MPa}$ & $\%$ & \\
\hline & \multirow{2}{*}{ Saturated } & $\mathrm{UCS}=0.03 \cdot \mathrm{e}^{3.41 \rho_{\text {sat }}}$ & $\mathrm{MPa}$ & $\mathrm{g} / \mathrm{cm}^{3}$ & \\
\hline & & $\mathrm{UCS}=185.88 \cdot \mathrm{e}^{-0.05 p}$ & $\mathrm{MPa}$ & $\%$ & \\
\hline \multirow{4}{*}{$\begin{array}{l}\text { Erguler and Ulusay } \\
\qquad(2009)[22]\end{array}$} & \multirow{2}{*}{ Dry } & $\mathrm{UCS}=0.03 \cdot \mathrm{e}^{3.41 \gamma_{d}}$ & $\mathrm{MPa}$ & $\mathrm{kN} / \mathrm{m}^{3}$ & \multirow{4}{*}{ Clay bearing rocks } \\
\hline & & $\mathrm{UCS}=393.1 \cdot \mathrm{p}^{-0.8474}$ & $\mathrm{MPa}$ & $\%$ & \\
\hline & \multirow{2}{*}{ Saturated } & $\mathrm{UCS}=0.13 \cdot \mathrm{e}^{0.2134 \gamma_{d}}$ & $\mathrm{MPa}$ & $\mathrm{kN} / \mathrm{m}^{3}$ & \\
\hline & & $\mathrm{UCS}=204.8 \cdot \mathrm{p}^{-1.1206}$ & $\mathrm{MPa}$ & $\%$ & \\
\hline \multirow{2}{*}{$\begin{array}{l}\text { Karakul and Ulusay } \\
\text { (2013) [12] }\end{array}$} & Dry & $\mathrm{UCS}=7.182 \cdot \mathrm{V}_{p}^{1.600}$ & $\mathrm{MPa}$ & $\mathrm{km} / \mathrm{s}$ & \multirow{2}{*}{ Several types } \\
\hline & Saturated & $\mathrm{UCS}=3.774 \cdot \mathrm{V}_{p}^{1.706}$ & $\mathrm{MPa}$ & $\mathrm{km} / \mathrm{s}$ & \\
\hline \multicolumn{6}{|c|}{ Relationships between physical properties and the $E_{\text {st }}$} \\
\hline \multirow{2}{*}{ Vásárhelyi (2005) [10] } & Dry & $E_{s t}=0.0088 \cdot \mathrm{e}^{3.126 \rho_{d}}$ & $\mathrm{GPa}$ & $\mathrm{g} / \mathrm{cm}^{3}$ & \multirow{2}{*}{ Limestones } \\
\hline & Saturated & $E_{s t}=0.0005 \cdot \mathrm{e}^{4.063 \rho_{s a t}}$ & $\mathrm{GPa}$ & $\mathrm{g} / \mathrm{cm}^{3}$ & \\
\hline \multirow{4}{*}{ Kim et al. (2017) [16] } & \multirow{2}{*}{ Dry } & $E_{s t}=0.22 \cdot \mathrm{e}^{1.89 \rho_{d}}$ & $\mathrm{GPa}$ & $\mathrm{g} / \mathrm{cm}^{3}$ & \multirow{4}{*}{ Sandstones } \\
\hline & & $E_{s t}=32.49 \cdot \mathrm{e}^{-0.05 \mathrm{p}}$ & $\mathrm{GPa}$ & $\%$ & \\
\hline & Saturated & $E_{s t}=0.004 \cdot \mathrm{e}^{3.45 \rho_{s a t}}$ & $\mathrm{GPa}$ & $\mathrm{g} / \mathrm{cm}^{3}$ & \\
\hline & saturated & $E_{s t}=30.06 \cdot \mathrm{e}^{-0.05 \mathrm{p}}$ & $\mathrm{GPa}$ & $\%$ & \\
\hline & Dry & $E_{s t}=0.062 \cdot \mathrm{e}^{0.2058 \gamma_{d}}$ & $\mathrm{GPa}$ & $\mathrm{kN} / \mathrm{m}^{3}$ & \\
\hline Erguler and Ulusay & & $E_{s t}=72.3 \cdot \mathrm{p}^{-1.0583}$ & Gpa & $\%$ & Clay bearing rocks \\
\hline (2009) [22] & Saturated & $E_{s t}=0.005 \cdot \mathrm{e}^{0.2711 \gamma_{s a t}}$ & $\mathrm{GPa}$ & $\mathrm{kN} / \mathrm{m}^{3}$ & Clay Dearing rocks \\
\hline & saturatea & $E_{s t}=60.5 \cdot \mathrm{p}^{-1.4375}$ & $\mathrm{GPa}$ & $\%$ & \\
\hline Brotons et al. (2016) [23] & Dry & $E_{s t}=0.679 \cdot \mathrm{V}_{p}^{2.664}$ & $\mathrm{GPa}$ & $\mathrm{km} / \mathrm{s}$ & Different types \\
\hline Horsrud (2001) [24] & Dry & $E_{s t}=0.076 \cdot \mathrm{V}_{p}^{3.23}$ & $\mathrm{GPa}$ & $\mathrm{km} / \mathrm{s}$ & Shale \\
\hline Najibi et al. (2015) [25] & Dry & $E_{s t}=0.169 \cdot \mathrm{V}_{p}^{3.324}$ & $\mathrm{GPa}$ & $\mathrm{km} / \mathrm{s}$ & Limestone \\
\hline Eissa and Kazi (1988) [26] & Dry & $E_{s t}=0.74 \cdot E_{d y n}-0.82$ & $\mathrm{GPa}$ & $\mathrm{GPa}$ & Several types \\
\hline $\begin{array}{c}\text { Christaras et al (1994) } \\
\text { [27] } \\
\end{array}$ & Dry & $E_{s t}=1.05 \cdot E_{d y n}-3.16$ & $\mathrm{GPa}$ & GPa & Several types \\
\hline Brotons et al. (2014) [28] & Dry & $E_{s t}=0.867 \cdot E_{d y n}-2.085$ & $\mathrm{GPa}$ & $\mathrm{GPa}$ & Calcarenite \\
\hline & & tionships between physical pro & ties and th & (50) & \\
\hline Awang et al.(2017) [29] & Dry & $I_{s(50)}=0.0007 \cdot V_{p}+0.1587$ & $\mathrm{MPa}$ & $\mathrm{m} / \mathrm{s}$ & Shale \\
\hline $\begin{array}{l}\text { Jamshidi et al. (2016) } \\
\text { [30] }\end{array}$ & Dry & $I_{s(50)}=6.67 \cdot \ln \left(V_{p}\right)-51.9$ & $\mathrm{MPa}$ & $\mathrm{m} / \mathrm{s}$ & Travertines \\
\hline Kurtulus et al. (2010) [31] & Dry & $I_{s(50)}=0.0018 \cdot V_{p}-1.9906$ & $\mathrm{MPa}$ & $\mathrm{m} / \mathrm{s}$ & Andesite \\
\hline Kurtulus et al. (2012) [32] & Dry & $I_{s(50)}=0.0042 \cdot V_{p}-14.602$ & $\mathrm{MPa}$ & $\mathrm{m} / \mathrm{s}$ & Serpentinized rocks \\
\hline
\end{tabular}

The above-mentioned points indicate that there is a need to study in more detail the effect of water content on mechanical properties of building stones. The specific objectives of this research are: firstly, to quantify the effect of water saturation on strength and deformability of porous calcareous building stones from the SE of Spain; secondly, to establish correlations between the dry and saturated physical, deformational and mechanical properties of these rock 
materials; and thirdly, to propose relationships between physical, deformational and mechanical properties for both states.

\section{MATERIALS AND METHODS}

\subsection{Rocks description and samples preparation}

The building stones tested in this research are four allochemical calcareous rocks extracted from a Tertiary transgressive unit (Medium-Upper Miocene). Fig. 2 shows their mesoscopic aspect. Three respective rock blocks of Blue (BC-BL), Beige (BC-BG) and Diamond (BC-DM) varieties were used in this research due to their high homogeneity, while for yellow calcarenite (BC-Y) two different rocks blocks were used because of its greater heterogeneity (BC- $Y 1$ and $B C-Y 2$ ).
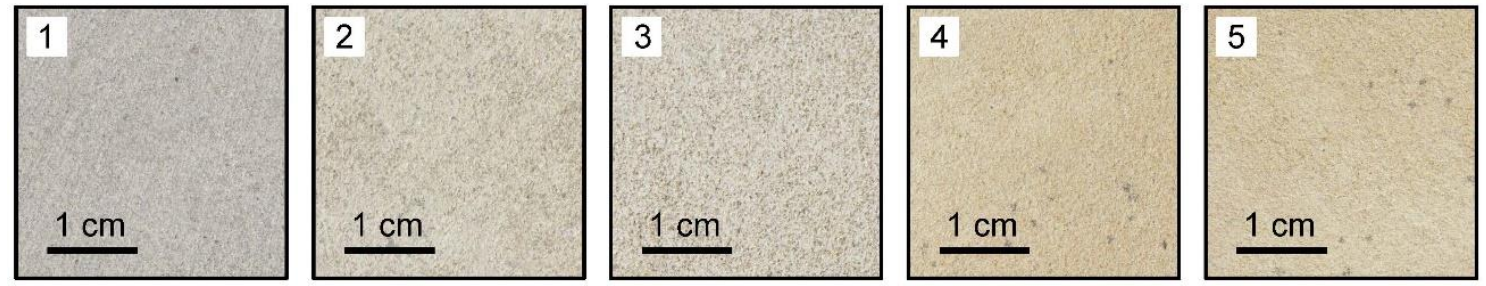

Fig 2. Mesoscopic aspect of the studied rocks: (1) Calcarenite-Blue (BC-BL); (2) Calcarenite-Beige (BC-BG); (3) Calcarenite-Diamond (BC-DM); (4) Calcarenite-Yellow-1 (BC-Y1); (5) Calcarenite-Yellow-2 (BC-Y2).

Cylindrical core samples with diameters of $28 \mathrm{~mm}$ and lengths of 70-75 $\mathrm{mm}$ were extracted from each block with a diamond drill rig. These dimensions were chosen to ensure a minimum slenderness ratio of 2.5 for $P$ and $S$ ultrasonic wave velocity $\left(V_{p}\right.$ and $\left.V_{s}\right)$, UCS and $E_{s t}$ tests as recommended by UNE Spanish standards [33]-[36]. Subsequently, for each variety of building stone, half of the samples were dried in an oven at $105^{\circ} \mathrm{C}$ until they reach a constant final mass to prepare the dry samples and the other half were soaked in water for $48 \mathrm{~h}$ in a vacuum chamber to obtain fully saturated samples.

\subsection{Mineralogical and petrographic analysis}

To characterize the chemical and mineralogical composition of the calcarenites, petrographic study of thin sections, determination of the carbonate content, X-ray diffraction (XRD) and X-ray fluorescence (XRF) analyses were performed. Petrographic examination was carried out using an OPTIKA B600POL petrographic microscope with the $\mathrm{X} 4$ objective lens. The thin-sections were obtained in a normal direction to the sedimentary bedding plane. Carbonate content was determined using a Bernard calcimeter according to UNE 103-200-93 standard [37]. XRD analysis was conducted using a Bruker D8-Advance X-Ray diffractometer with a generator of X-ray KRISTALLOFLEX K 760-80F and a tube of XR with a copper anode. XRF was performed using a Xray sequential spectrometer PHILIPS MAGIX PRO equipped with a rhodium X-ray tube and beryllium window and a single goniometer based measuring channel, covering the complete measuring range, according to ASTM E1621-13 [38].

\subsection{Physical properties}

The dry and saturated bulk densities $\left(\rho_{d}\right.$ and $\left.\rho_{\text {sat }}\right)$, open porosity $\left(p_{o}\right)$ and water absorption $\left(W_{a}\right)$ were calculated using traditional techniques by determining weights (i.e. dry, saturated and immersed) and specimen bulk volume. The true density $\left(\rho_{\mathrm{r}}\right)$ was determined using the 
pycnometers method and total porosity $(p)$ was indirectly calculated using the relationship between bulk and true density. All procedures were determined in accordance with the UNE Spanish standard [39][40]. Furthermore, the pore-size distribution of calcarenites was carried out through mercury intrusion porosimetry (MIP) tests using a POREMASTER-60 GT (Quantachrome Instruments) equipped with two low pressure stations plus two high pressure stations up to 60,000 psi.

The longitudinal $(P)$ and transverse $(S)$ wave velocities $\left(V_{p}\right.$ and $\left.V_{s}\right)$ of the calcarenites were determined using signal emitting-receiving machine (Proceq Pundit Lab+) docked with a computer. To calculate the corresponding wave velocity of each rock sample, its length (i.e. the distance between transducers) was divided by the travel time of each wave. The P-wave velocity was calculated according to UNE-EN 14579 [33]. The ultrasonic P-wave velocity $\left(\mathrm{V}_{\mathrm{p}}\right)$, ultrasonic S-wave velocity $\left(V_{s}\right)$ and bulk density $\left(\rho_{b}\right)$ were used to determine the dynamic Young's modulus $\left(E_{\text {dyn }}\right)$ and the dynamic Poisson's coefficient $\left(v_{\text {dyn }}\right)$ under dry and saturated conditions by using equations (1) and (2).

$$
\begin{gathered}
E_{d y n}=\frac{\left[\rho_{b} \cdot V_{s}^{2} \cdot\left(3 \cdot V_{p}^{2}-4 \cdot V_{s}^{2}\right)\right]}{V_{p}^{2}-V_{s}^{2}} \\
v_{d y n}=\frac{V_{p}^{2}-2 \cdot V_{s}^{2}}{\left[2 \cdot\left(V_{p}^{2}-V_{s}^{2}\right)\right]}
\end{gathered}
$$

\subsection{Strength and deformability tests}

A servo-controlled press machine with a $200 \mathrm{kN}$ capacity was used for the development of the UCS and deformability tests. Additionally, a specific instrument was used to measure the strain of the samples under dry and saturated conditions. This device consists in two metal rings joined and positioned in parallel along the axis of the specimen, and two diametrically opposed linear variable differential transducers (LVDT) to record changes in the relative distance between the rings (axial strain of the specimen) while the axial load is applied. Axial strain measurement was attained up to a maximum value equal to $50 \%$ of the ultimate load of the specimen in order to obtain the secant Young's modulus ( $\left.E_{s t}\right)$ according to UNE 22950-3 [35]. Once the deformability test was concluded, the rings were removed from the sample and the loading test was restarted until failure. The loading rate was adjusted to make sure that the failure samples in dry and saturated states happened between 5 and 10 minutes after the start of the test as required by UNE 22950-1 [34].

In addition to $E_{s t}$ and UCS, the $I_{s(50)}$ of calcarenites was determined. In particular, twelve values of $I_{s(50)}$ were obtained in dry and saturated conditions for each type of calcarenite. The diametral PLT tests were carried out according to UNE 22950-5 standard [36].

\section{RESULTS}

\subsection{Chemical, mineralogical and microscopic analysis}

XRF analyses indicate that the main chemical compounds of the calcarenite samples expressed in percentage are $\mathrm{CaO}$ (41.88-44.34), $\mathrm{SiO}_{2}$ (8.13-14.27), $\mathrm{SO}_{3}$ (0.25-6.87), $\mathrm{MgO}(0.74-2.54), \mathrm{Al}_{2} \mathrm{O}_{3}$ 
(0.79-1.78), $\mathrm{Fe}_{2} \mathrm{O}_{3}(0.56-1.13)$ and $\mathrm{K}_{2} \mathrm{O}_{3}(0.26-0.63)$ besides the loss on ignition (LOI) (30.4044.42). The full chemical analysis is given in Table 3.

\begin{tabular}{|c|c|c|c|c|}
\hline & BC-BL & BC-BG & BC-DM & $B C-Y$ \\
\hline Compound & $(\%)$ & $(\%)$ & $(\%)$ & $(\%)$ \\
\hline $\mathrm{Na}_{2} \mathrm{O}$ & - & - & - & 0.238 \\
\hline $\mathrm{MgO}$ & 2.538 & 2.380 & 1.674 & 0.735 \\
\hline $\mathrm{Al}_{2} \mathrm{O}_{3}$ & 1.784 & 1.712 & 1.130 & 0.789 \\
\hline $\mathrm{SiO}_{2}$ & 14.272 & 14.242 & 13.802 & 8.131 \\
\hline $\mathrm{P}_{2} \mathrm{O}_{5}$ & 0.093 & 0.107 & 0.104 & - \\
\hline $\mathrm{SO}_{3}$ & 6.871 & 3.063 & 1.442 & 0.250 \\
\hline $\mathrm{K}_{2} \mathrm{O}$ & 0.598 & 0.630 & 0.516 & 0.257 \\
\hline $\mathrm{CaO}$ & 41.879 & 43.263 & 43.667 & 44.339 \\
\hline $\mathrm{TiO}_{2}$ & 0.051 & 0.054 & 0.064 & 0.042 \\
\hline $\mathrm{Fe}_{2} \mathrm{O}_{3}$ & 0.952 & 1.130 & 0.719 & 0.564 \\
\hline $\mathrm{SrO}$ & 0.185 & 0.133 & 0.114 & 0.136 \\
\hline 1 & 0.005 & 0.002 & - & - \\
\hline $\mathrm{BaO}$ & 0.052 & 0.079 & 0.042 & - \\
\hline $\mathrm{WO}_{3}$ & 0.322 & 0.132 & 0.152 & 0.101 \\
\hline LOI & 30.400 & 33.070 & 36.580 & 44.420 \\
\hline Total & 100.002 & 99.997 & 100.006 & 100.002 \\
\hline
\end{tabular}

The XRD patterns of the calcarenites are shown in Fig. 3. According to the XRD analyses, the four calcarenite varieties contain dominantly calcite (approximately $70-80 \%$ for Bateig varieties and $90 \%$ for yellow varieties) and quartz (5-15\% for Bateig varieties and 5-10\% for the yellow one). Furthermore, the three Bateig calcarenites present dolomite (5-10\%). Additionally, phyllosilicates (5-10\%) and small quantities of calcium silicate were found in BC-BL and BC-BG while ankerite was detected in BC-DM and BC-BG. In line with above-mentioned results, Bernard's calcimeter tests revealed that calcite contents were 76.0, 77.2, 73.6 and $92.7 \%$ for BC$B L, B C-B G, B C-D M$ and $B C-Y$, respectively.

The thin sections analysis indicated some small differences of textural and mineralogical properties of the studied rocks. Blue calcarenite is a biomicrite whose main components are fossil elements, specifically foraminifera (Globorotalia, Globigerina, Rotalidae and Textularidae), bryozoans and echinoderms. As regards the terrigenous components, we have identified mainly quartz (monocrystalline and polycrystalline), potassium feldspar, dolostone extraclasts, phyllosilicates (smectite, mica and palygorskite) and clay galls. Small amounts of orthochems (micritic matrix and sparry cement) and siliceous fibrous cement were also found. Beige calcarenite is very similar to Blue variety from the petrographic point of view. It is a micrite whose majority components are fossil elements like foraminifera, bryozoans and molluscs. Concerning terrigenous components, monocrystalline quartz, dolostone clasts and small amounts of feldspars have been identified. Furthermore, authigenic constituents (phyllosilicates like smectite, mica and glauconite) have been also found. For its part, Diamond calcarenite is a biomicrite mainly composed of fossil elements (Globerina, Heterostegina, Rotalidae and Turborotalia). As for the terrigenous components, quartz (monocrystalline), potassium feldspar and clay galls have been observed. Concerning orthochems, micrite is the most abundant component [41]. Yellow calcarenites (BC-Y1 and BC-Y2) are very similar to one another in terms 
of texture and mineralogy. BC-Y1 is slightly more porous and weathered than BC-1. In any case, both are very porous stones and can be classified as packstones [42]. Texturally, these rocks present abundant allochemicals, with grain size considerably smaller than the other varieties (less than $0.5 \mathrm{~mm}$ ). Their majority components are fossil elements (mainly foraminifera, bryozoans and echinoderms). The ortochemical fraction corresponds principally to micrite. Its main terrigenous component is quartz. In addition, glauconite have also been identified in both types. Thin section microphotographs of the four calcarenites taken with parallel light and crossed nicols are shown in Fig. 4.
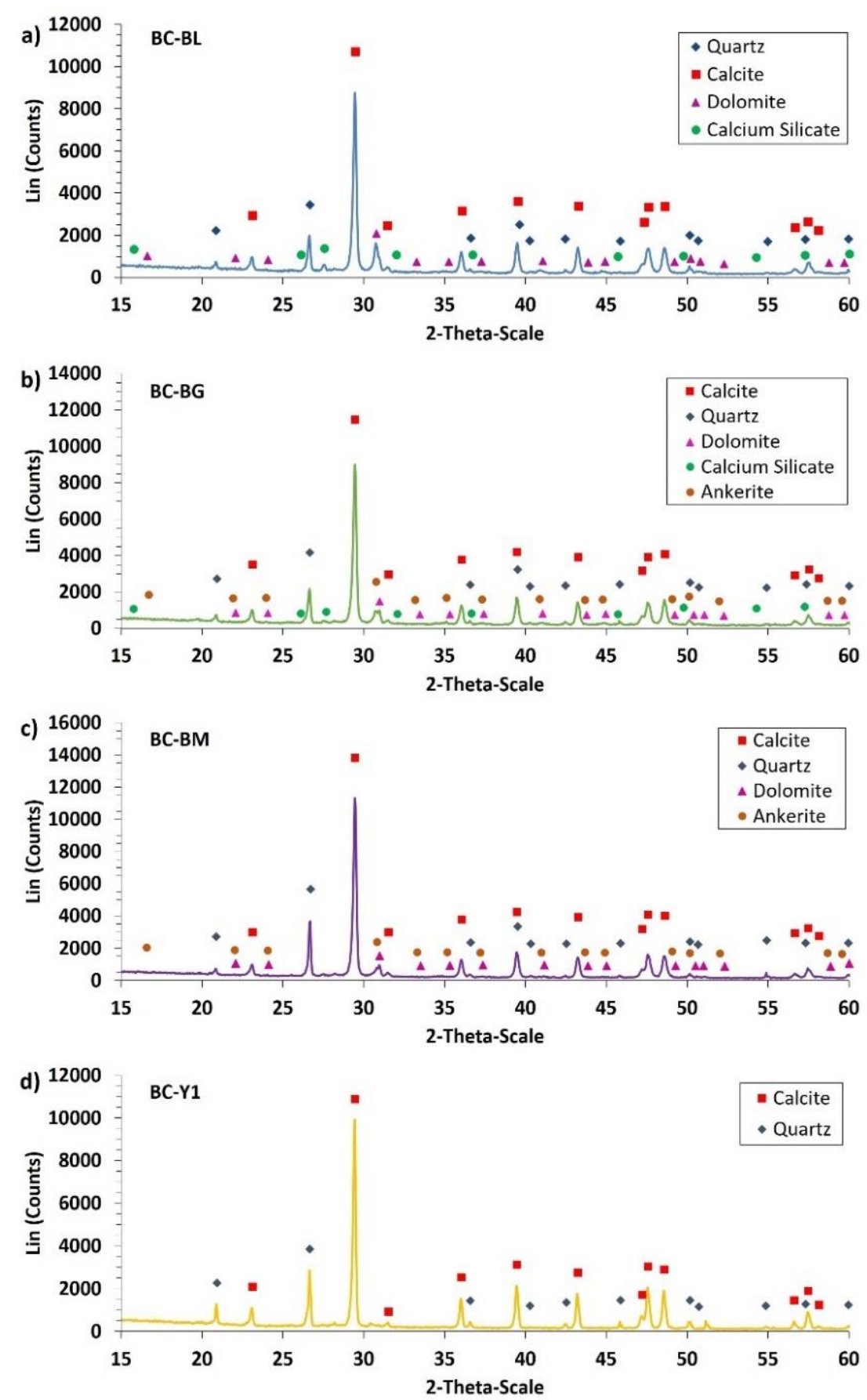

Fig.3. XRD analyses of Blue (BC-BL) (a), Beige (BC-BG) (b), Diamond (BC-DM) (c) and yellow (BC-Y1) (d) calcarenites. 

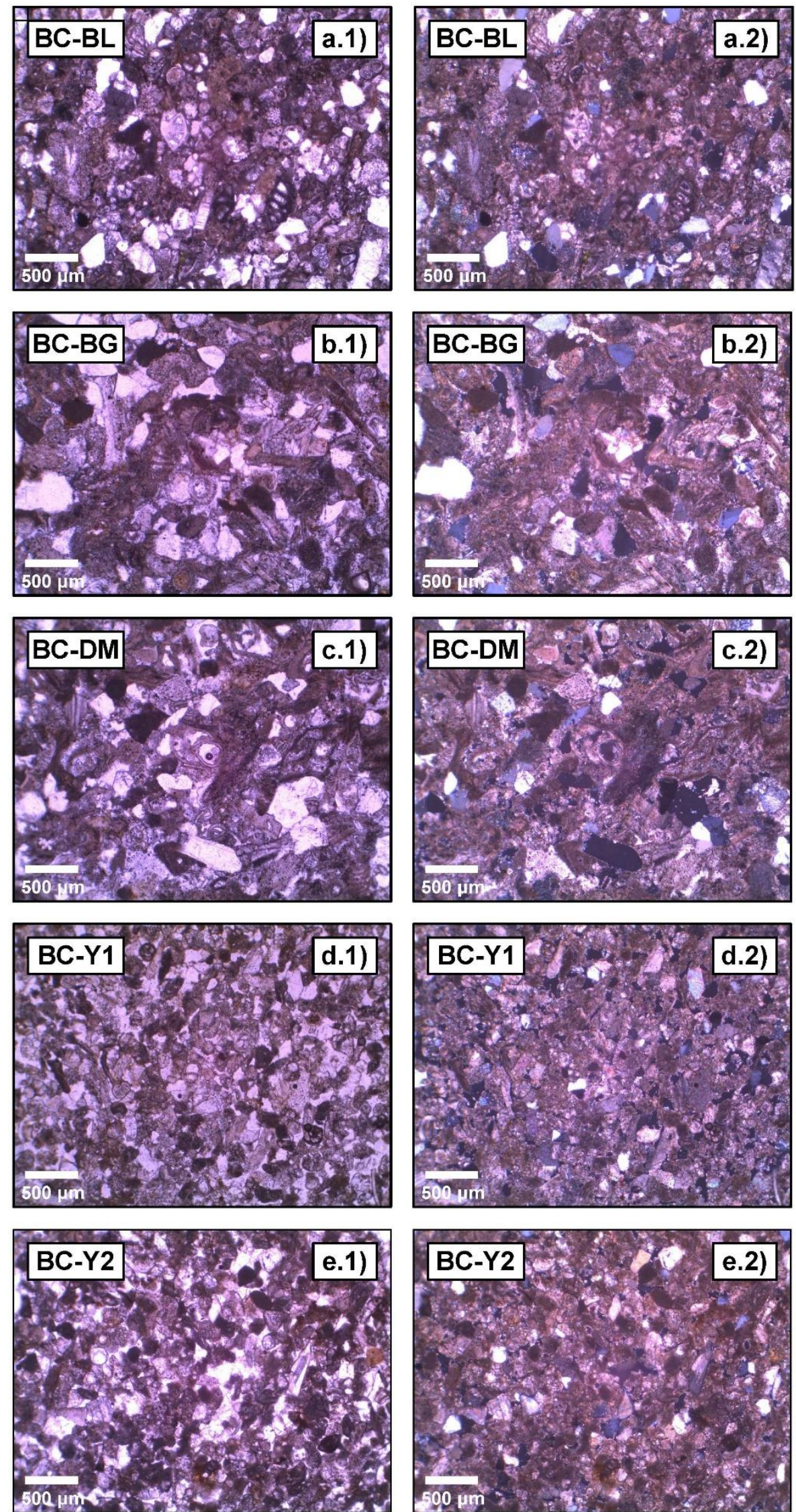

Fig. 4. Thin section microphotographs taken with parallel light (a.1, b.1, c.1, d.1 and e.1) and crossed nicols (a.2, b.2, c.2, d.2 and e.2) of Blue (BC-BL), Beige (BC-BG), Diamond (BC-DM) and yellow (BC-Y1 and BC-Y2) calcarenites, respectively. 


\subsection{Physical properties}

Dry and saturated bulk densities of calcarenite varieties varied between $1.87-2.29 \mathrm{~g} / \mathrm{cm}^{3}$ and 2.19-2.41 g/ $/ \mathrm{cm}^{3}$, respectively. The highest bulk density value corresponded to the Blue calcarenite and the lowest value was found in yellow variety. In line with this, the Blue variety showed the smallest open and total porosities (i.e. 11.65 and $14.92 \%$, respectively) and water absorption capacity (i.e. 5.07\%) while the yellow calcarenite showed the greatest mean values of these properties (i.e. 28.78, 29.22 and $15.06 \%$, respectively). For its part, Diamond and Beige varieties exhibited intermediate and similar densities and porosities values each other. The physical properties of rock blocks are summarized in Table 4.

\begin{tabular}{|c|c|c|c|c|c|c|c|}
\hline & $\mathbf{N}$ & & $\begin{array}{c}\boldsymbol{\rho}_{\mathbf{d}} \\
\left(\mathrm{g} / \mathrm{cm}^{3}\right)\end{array}$ & $\begin{array}{c}\rho_{\text {sat }} \\
\left(\mathrm{g} / \mathrm{cm}^{3}\right)\end{array}$ & $\begin{array}{l}\text { po }_{0} \\
(\%)\end{array}$ & $\begin{array}{c}\mathbf{p} \\
(\%)\end{array}$ & $\begin{array}{l}W_{a} \\
(\%)\end{array}$ \\
\hline BC-BL & 12 & $x \pm \sigma$ & $2.29 \pm 0.01$ & $2.41 \pm 0.01$ & $11.65 \pm 0.37$ & $14.92 \pm 0.26$ & $5.07 \pm 0.17$ \\
\hline BC-BG & 12 & $\chi \pm \sigma$ & $2.16 \pm 0.01$ & $2.35 \pm 0.01$ & $18.12 \pm 0.39$ & $20.29 \pm 0.36$ & $8.35 \pm 0.22$ \\
\hline BC-DM & 12 & $\chi \pm \sigma$ & $2.12 \pm 0.01$ & $2.32 \pm 0.01$ & $20.26 \pm 0.26$ & $21.66 \pm 0.30$ & $9.52 \pm 0.16$ \\
\hline BC-Y1 & 12 & $\chi \pm \sigma$ & $1.87 \pm 0.02$ & $2.19 \pm 0.01$ & $28.78 \pm 0.75$ & $29.22 \pm 0.77$ & $15.06 \pm 0.57$ \\
\hline BC-Y2 & 12 & $\chi \pm \sigma$ & $1.94 \pm 0.03$ & $2.22 \pm 0.02$ & $26.57 \pm 1.13$ & $26.93 \pm 1.15$ & $13.54 \pm 0.78$ \\
\hline
\end{tabular}

With regard to the pore size distributions, the MIP indicated that Blue calcarenite presents the smallest pores (diameters mostly between 0.03 and $0.5 \mu \mathrm{m}$ ), while yellow calcarenite has the biggest pores (diameters mostly between 5 and $20 \mu \mathrm{m}$ ). For its part, Beige and Diamond show quite similar pore size distributions (and mainly pores with diameters between 0.1 and $10 \mu \mathrm{m}$ ). Additionally, yellow calcarenite exhibits a very uniform distribution of pore size of $10 \mu \mathrm{m}$ (Fig. 5).
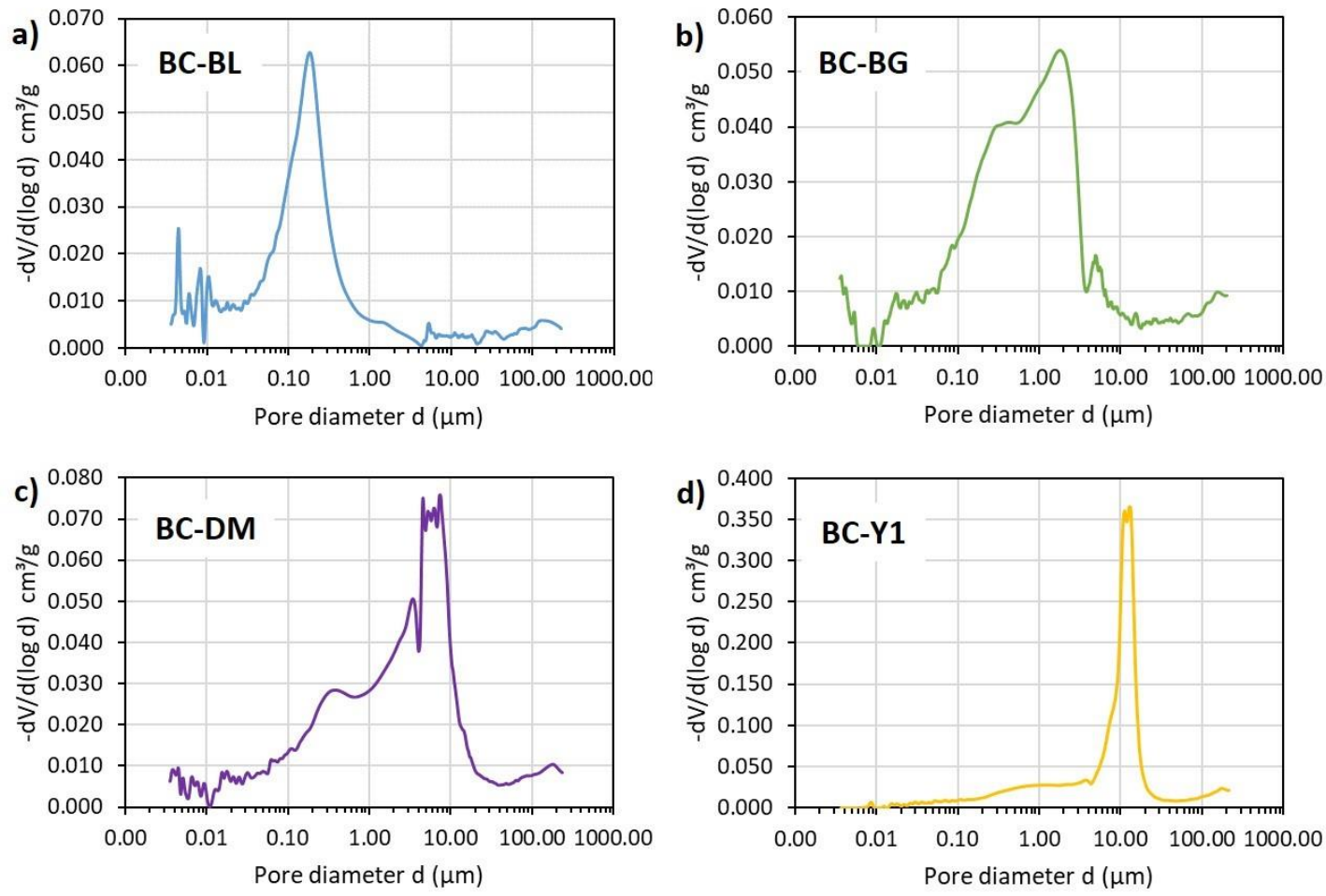

Fig. 5. Pore-size distributions measured by mercury intrusion porosimetry tests in Blue (BC-BL) (a), Beige (BC-BG) (b), Diamond (BCDM) (c) and yellow (BC-Y1) (d) calcarenites. 


\subsection{Ultrasonic wave velocities $\left(V_{p}\right.$ and $\left.V_{s}\right)$ and dynamic parameters $\left(E_{d y n}\right.$ and $\left.V_{d y n}\right)$ in dry and saturated conditions}

Concerning P-and S-wave velocities in dry state, the highest mean values were obtained in Blue calcarenite samples $(4.61$ and $2.66 \mathrm{~km} / \mathrm{s})$ and the lowest values were measured in yellow calcarenite (2.07 and $1.38 \mathrm{~km} / \mathrm{s}$ in BC-Y1). Diamond and Beige calcarenite exhibited intermediate mean values of $V_{p}\left(4.17\right.$ and $3.32 \mathrm{~km} / \mathrm{s}$, respectively) and $V_{s}(2.41$ and $2.03 \mathrm{~km} / \mathrm{s}$, respectively). The same hierarchical order remained in saturated specimens. The results are summarized in Table 5.

With regard to the influence of water saturation on $V_{p}$, two different behaviours were observed. Blue, Beige and Diamond calcarenites showed a moderate increase (i.e. 5.6, 4.2 and 13.0\%) while yellow variety exhibited an important decrease (i.e. $40.9 \%$ in BC-Y1 and $20.3 \%$ in BC-Y2) when saturated. Regarding the variation of $\mathrm{V}_{\mathrm{s}}$, all stones exhibited a reduction in this parameter when saturated. The smallest $V_{s}$ decrease was found in Diamond calcarenite (3.2\%) while the greater loss was obtained in yellow variety (45.4\% in BC-Y1). Blue and Beige calcarenites showed moderate $\mathrm{V}_{\mathrm{s}}$ reductions ( 7.2 and $13.8 \%$, respectively).

Concerning $\mathrm{E}_{\mathrm{dyn}}$ in dry state, the highest value was obtained in Blue calcarenite (40.49 GPa) and the lowest value was measured in yellow variety (7.79 GPa in BC-Y1). For its part, Diamond and Beige calcarenites showed intermediate values (30.66 and $21.37 \mathrm{GPa}$, respectively). Regarding the $v_{\text {dyn }}$ in dry state, the highest mean values were obtained in Blue and Diamond calcarenites (i.e. 0.25) and the smallest values were found in yellow variety (0.14 in BC-Y2). Similar hierarchical order remained in both parameters in saturated samples.

With respect to water saturation effect on these dynamic parameters, the results suggested a slight reduction of $E_{d y n}$ in Blue and Beige calcarenites (8.7 and 17.8\%, respectively), irrelevant changes in Diamond variety and a marked decrease in yellow calcarenite specimens (67.2 in BC$\mathrm{Y} 1$ and $47.0 \%$ in $\mathrm{BC}-\mathrm{Y} 2$ ) when saturated. Furthermore, an important increase in $\mathrm{v}_{\mathrm{dyn}}$ was noticed for all studied stones after the water saturation. All results are shown in Table 5.

Table 5. $P$ and $S$ ultrasonic wave velocities $\left(V_{p}\right.$ and $\left.V_{s}\right)$, dynamic elastic modulus ( $\left.E_{\text {dyn }}\right)$ and dynamic Poisson coefficient ( $\left.V_{\text {dyn }}\right)$ of dry and saturated calcarenites. $\mathrm{N}$ : number of core samples; $\chi$ : mean value; $\sigma$ : standard deviation.

\begin{tabular}{|c|c|c|c|c|c|c|c|c|c|c|}
\hline \multirow{2}{*}{\multicolumn{2}{|c|}{$\mathrm{N}$}} & & \multicolumn{4}{|c|}{ Dry } & \multicolumn{4}{|c|}{ Saturated } \\
\hline & & & $\begin{array}{r}V_{p} \\
(k m / s)\end{array}$ & $\begin{array}{c}V_{s} \\
(\mathrm{~km} / \mathrm{s})\end{array}$ & $\begin{array}{l}V_{\text {dyn }} \\
(-)\end{array}$ & $\begin{array}{c}E_{d y n} \\
(G P a)\end{array}$ & $\begin{array}{c}V_{p} \\
(\mathrm{~km} / \mathrm{s})\end{array}$ & $\begin{array}{c}V_{\mathrm{s}} \\
(\mathrm{km} / \mathrm{s})\end{array}$ & $\begin{array}{l}V_{\text {dyn }} \\
(-)\end{array}$ & $\begin{array}{c}E_{d y n} \\
(G P a)\end{array}$ \\
\hline BC-BL & 12 & $\chi \pm \sigma$ & $4.61 \pm 0.02$ & $2.66 \pm 0.04$ & $0.25 \pm 0.01$ & $40.49 \pm 0.93$ & $4.87 \pm 0.13$ & $2.46 \pm 0.04$ & $0.33 \pm 0.01$ & $36.98 \pm 1.37$ \\
\hline BC-BG & 12 & $\chi \pm \sigma$ & 2 & 6 & $0.2 \mathrm{C}$ & 2 & 3. & 04 & 1 & 17 \\
\hline BC-DM & 12 & $\chi \pm \sigma$ & 4 & 2 & 0. & & 44 & 1 & & \\
\hline BC-Y1 & 12 & $\chi \pm \sigma$ & & 1. & & & & & & \\
\hline BC-Y2 & 12 & $\chi \pm \sigma$ & $2.49 \pm 0.15$ & $1.61 \pm 0.09$ & $0.14 \pm 0.04$ & $11.45 \pm 1.49$ & $1.99 \pm 0.20$ & $1.12 \pm 0.08$ & $0.27 \pm 0.02$ & $6.18 \pm 0.99$ \\
\hline
\end{tabular}

\subsection{Static Young's modulus ( $\left.E_{s t}\right)$, unconfined compressive strength (UCS) and point load strength index $\left(I_{s(50)}\right)$ in dry and saturated conditions.}

The highest mean values of UCS, $E_{s t}$ and $I_{s(50)}$ in dry conditions were obtained in Blue calcarenite (36.58 $\mathrm{MPa}, 25.02 \mathrm{GPa}$ and $3.93 \mathrm{MPa}$, respectively) and the smallest mean values were measured in yellow calcarenite (7.87 MPa, 2.61 GPa and 0.45 MPa in BC-Y1 and 10.28 MPa, 4.93 $\mathrm{GPa}$ and 0.72 in $\mathrm{BC}-\mathrm{Y} 2$, respectively). Furthermore, intermediate mean values were found in Beige (21.51 MPa, 7.73 GPa and 1.80 MPa, for UCS, $E_{s t}$ and $I_{s(50)}$, respectively) and in Diamond 
(26.90 MPa, 19.88 GPa and 2.80 MPa for UCS, $E_{s t}$ and $I_{s(50)}$, respectively) varieties. However, in saturated conditions, the highest values of UCS and $\mathrm{E}_{\mathrm{st}}$ were measured in Diamond calcarenite (18.89 $\mathrm{MPa}$ and $15.39 \mathrm{GPa}$ ) which indicates a lower water saturation sensitivity of this variety. The results are summarized in Fig.6.

Concerning the influence of water saturation on strength and deformability of calcarenites, the findings indicated that very important reductions in UCS, $\mathrm{E}_{\mathrm{st}}$ and $\mathrm{I}_{\mathrm{S}(50)}$ occurred in Blue $(48.9,53.1$ and $49.6 \%)$, Beige $(61.9,68.3$ and $55.6 \%)$ and yellow calcarenites $(63.9,59.0$ and $49.3 \%$ in BC-Y1 and 49.6, 58.0 and $38.6 \%$ in BC-Y2, respectively). However, Diamond variety exhibited a lower loss of these properties $(29.8,22.6$ and $34.6 \%)$, suggesting a better mechanical behaviour in wet environments of this variety, as it has been previously mentioned (Fig. 6).
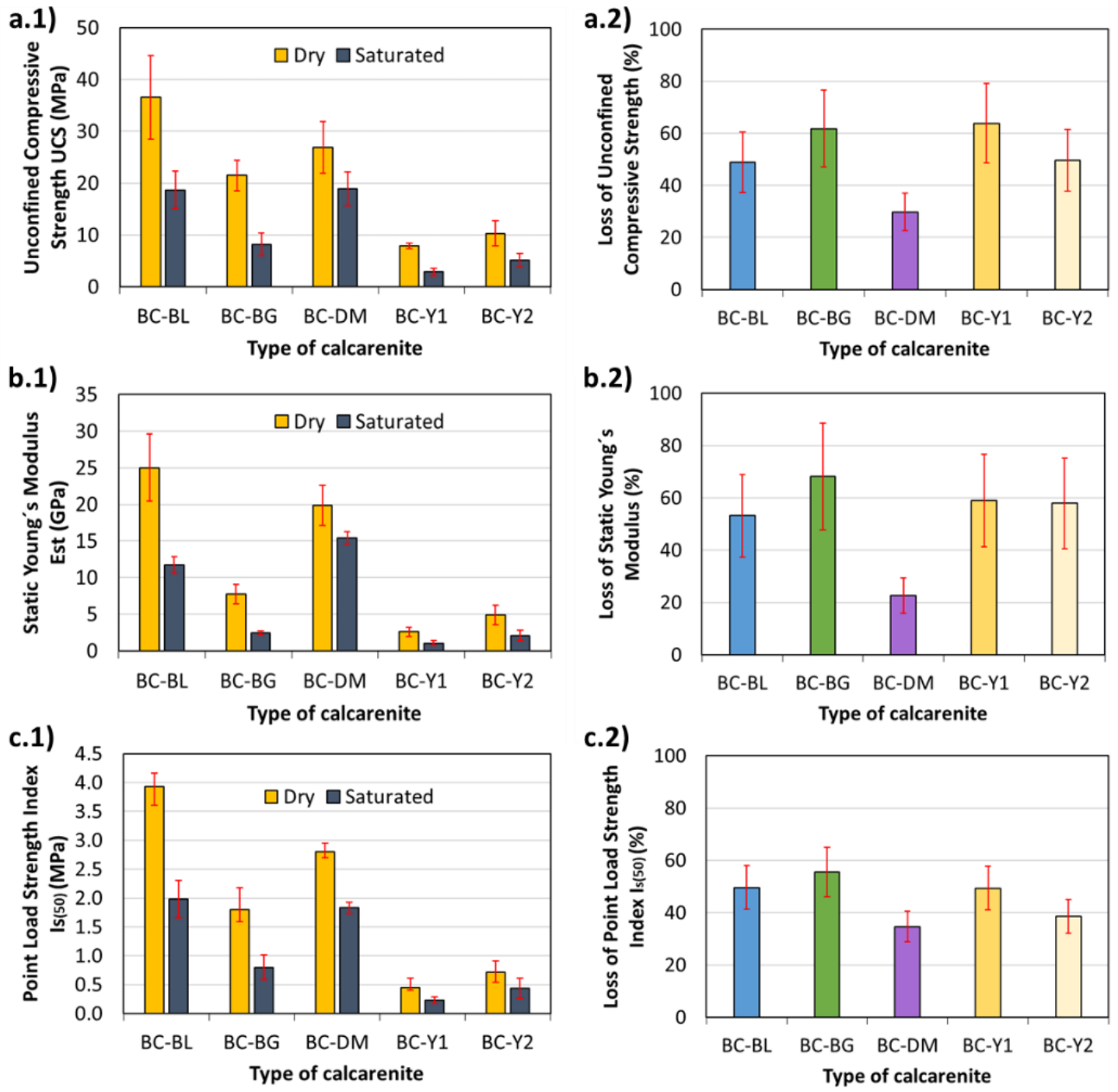

Fig. 6. UCS, $E_{s t}$ and $I_{s(50)}$ under dry and saturated conditions (a.1, b.1 and c.1) and \% losses of UCS, $E_{s t}$ and $I_{s(50)}(a .2, b .2, c .2)$ in Blue, Beige, Diamond and Yellow calcarenites.

\section{ANALYSIS AND DISSCUSION}

4.1. Variation of ultrasonic wave velocities $\left(V_{p}\right.$ and $\left.V_{s}\right)$ and dynamic parameters $\left(E_{d y n}\right.$ and $\left.v_{d y n}\right)$ due to water saturation 
There are two factors affecting the changes induced in $\mathrm{V}_{\mathrm{p}}$ caused by saturation. On the one hand, when a rock is saturated bulk modulus and pore pressure increase and, therefore, an increment of stiffness and $V_{p}$ is exhibited. On the other hand, a decrease of $V_{p}$ occurred due to the loss of stiffness in rock solid matrix due to water saturation [12]. Consequently, $V_{p}$ positive increments for whole rock (pores and solid matrix) obtained in Blue, Beige and Diamond calcarenites indicate an increment of effective modulus parameters. By contrast, negative increments for whole rock measured in yellow calcarenite suggest a reduction of modulus parameters. This different behaviour was also reported in Turkish sedimentary rocks by Karakul [12]. The average ratio obtained between $V_{p}$ in both conditions $\left(K_{v p}\right)$ for calcarenites was 1.015. The lineal regression analysis and a comparison with the findings obtained in other previous works can be observed in Fig. 7.a.
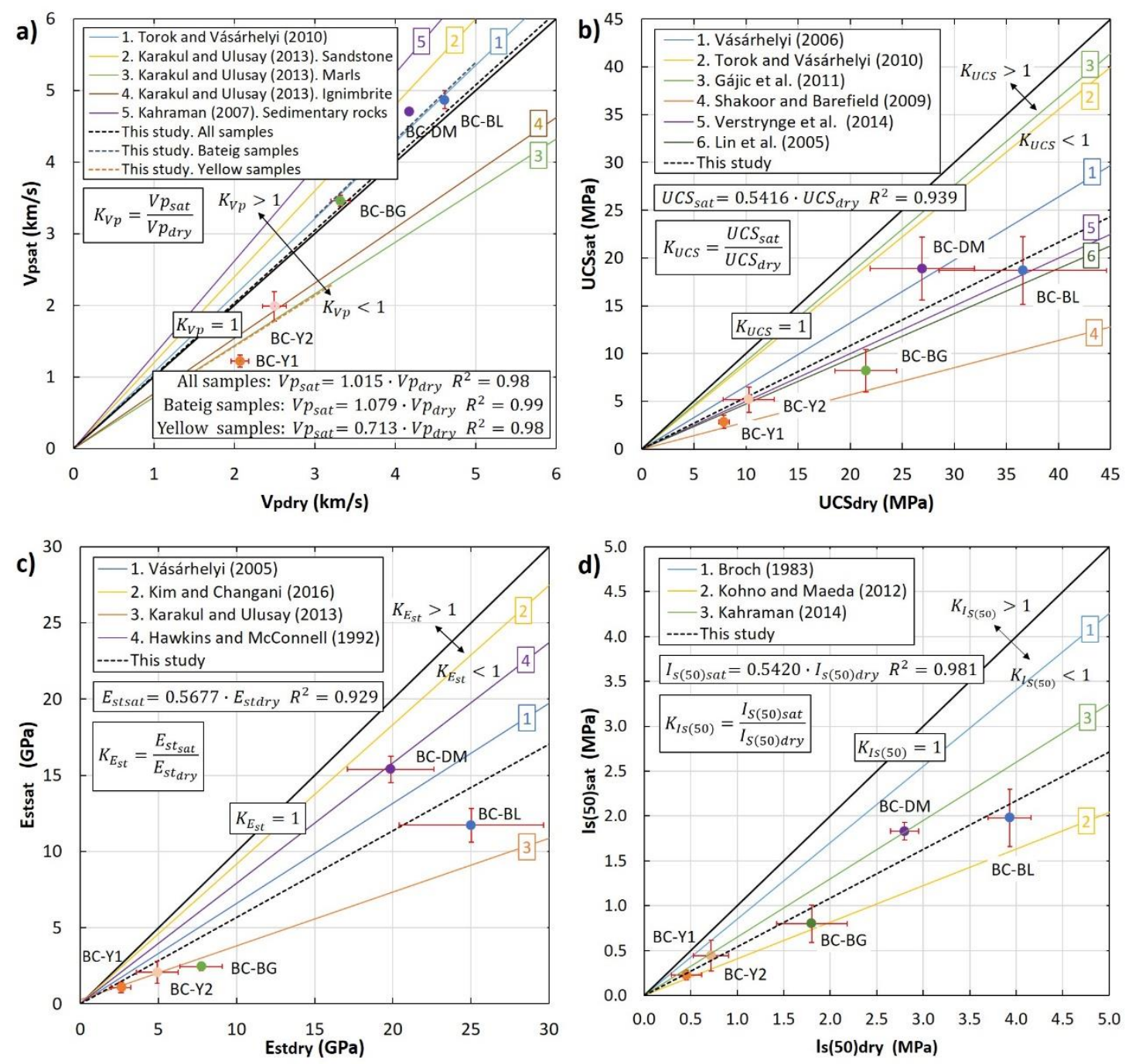

Fig. 7. Relationships between dry and saturated values of $V_{p}(a), U C S(b), E_{s t}(c)$ and $I_{s(50)}(d)$ for the studied calcarenites and comparison with other results published in scientific literature.

In addition, the reductions of $V_{s}$ measured in all calcarenite samples due to water saturation indicated that the change of $\mathrm{V}_{\mathrm{s}}$ is simpler than $\mathrm{V}_{\mathrm{p}}$. In this line, shear modulus was not influenced by saturation and according to the effective medium theory, $V_{s}$ reduced slightly with the increase of density. Similar findings were obtained in artificial sandstones by Si et al. [43]. 
Dynamic elastic modulus ( $\left.E_{d y n}\right)$ estimated from ultrasonic wave velocities were higher for dry specimens than for saturated samples in Blue, Beige and yellow calcarenites. This result is in agreement with those obtained by Kate [44] in sandstones. Specifically, yellow calcarenites showed the highest reduction of $E_{d y n}$ due to the greater $V_{p}$ and $V_{s}$ variations with saturation caused by its higher porosity, as suggested by Gregory [45] for sedimentary rocks. However, $E_{\text {dyn }}$ was not significantly different for Diamond variety because of the lighter water sensitivity of $\mathrm{V}_{s}$ obtained in this calcarenite type. As for dynamic Poisson's coefficient $\left(v_{\text {dyn }}\right)$, a significant increase was observed in all calcarenite varieties in line with the findings reported by Kate [44].

\subsection{Variation of mechanical properties due to water saturation}

In general, the results demonstrate a significant loss of strength and an increase of the deformability of the calcarenites as a consequence of their water saturation. These findings are similar to those obtained by other researchers in limestones and sandstones [6]-[11]. UCS, $E_{s t}$ and $\mathrm{Is}_{(50)}$ losses can be attributed to two different causes that may have taken place simultaneously. The first reason could be the decrease in surface energy of the crack borders when the pore is full of water [46]. In other words, moisture diminishes the spread of free surface energy, i. e. it facilitates micro-cracks propagation by decreasing the UCS and $E_{s t}$ [47]. The second cause could be the wakening of cementations between the grains by solution or dispersion (chemical and corrosive deterioration) [3] or the appearance of cracks due to the swelling of clay minerals. This effect can be very relevant in clay-bearing sandstones or argillaceous rocks [22], [48]. In this sense, it is important to note that the Blue and Beige Bateig calcarenites, which have phyllosilicates (smectite, mica and palygorskite), exhibit important reductions of $U C S, E_{s t}$ and $I_{s(50)}$.

Furthermore, micro-fabric and pore-size distribution are parameters that also partly influence the mechanical parameters of these stones. In this line, the calcarenites cemented by smaller calcite grains and with higher pore size (BC- $Y 1$ and $B C-Y 2)$ exhibit greater strength reductions due to water saturation than the varieties cemented by greater calcite grains and with lower pore diameters (BC-BL, BC-BG and BC-DM). These results are in agreement with those found by Török [49], Papay and Török [50] and Török and Szemerey-Kiss [51], [52], who observed that the limestones cemented by fine grained micrite calcite are more water sensitive in terms of strength and durability than those cemented by micro-sparitic calcite. In addition, they also found the existence of a close relationship between the pore structures and the mechanical properties of Hungarian limestones.

\subsubsection{Unconfined compressive strength loss. Correlations with physical and ultrasonic properties.}

The results showed the highest UCS loss in yellow calcarenites. This can possibly be explained by its greater porosity and water absorption capacity and its smaller UCS and cementation between the grains [3]. In addition, in respect of Bateig calcarenites, Blue and Beige exhibited a similar UCS loss as a result of their close petrological properties. However, Diamond variety showed the lowest UCS loss which may be associated by its lower content of clay minerals, as several authors suggest in others sedimentary rocks [9], [12].

In order to discuss and compare the UCS variations in calcarenite stones due to water saturation with the results obtained by others researchers, the UCS values in saturated state $\left(U C S_{\text {sat }}\right)$ were 
plotted as a function of the unconfined compressive strength figures in dry state (UCS dry $\left._{\text {ry }}\right)$ and a linear trend was found. The slope of trend line ( $\left.\mathrm{K}_{\mathrm{ucs}}\right)$ was 0.542 and suggested a mean compressive strength loss of $45.8 \%$. This strength loss is similar than that obtained in limestones by Vásárhelyi [10] and in ferruginous and tertiary sandstones by Verstringe et al. [9] and Lin et al [15], respectively; substantially higher than the findings reported in travertines by Torok et al. [11]; and considerably smaller than the results found in American sandstones by Shakoor and Barefield [8] as reflected in Fig. 7.b.

Concerning the second objective of this research, relationships between the physical properties and UCS of calcarenite stones in dry and water saturated conditions were established. Specifically, several function types were fitted (e.g., lineal, exponential, power, etc.) and finally the curve that best fitted the data (higher $\mathrm{R}^{2}$ ) was selected. In this case, significant correlations $(P$-value $<0,05)$ were obtained between UCS and physical properties like $\rho, V_{p}$ and $E_{\text {dyn }}$ under dry and saturated conditions (Fig. 8). Similar function types were found by others authors (Table 2).
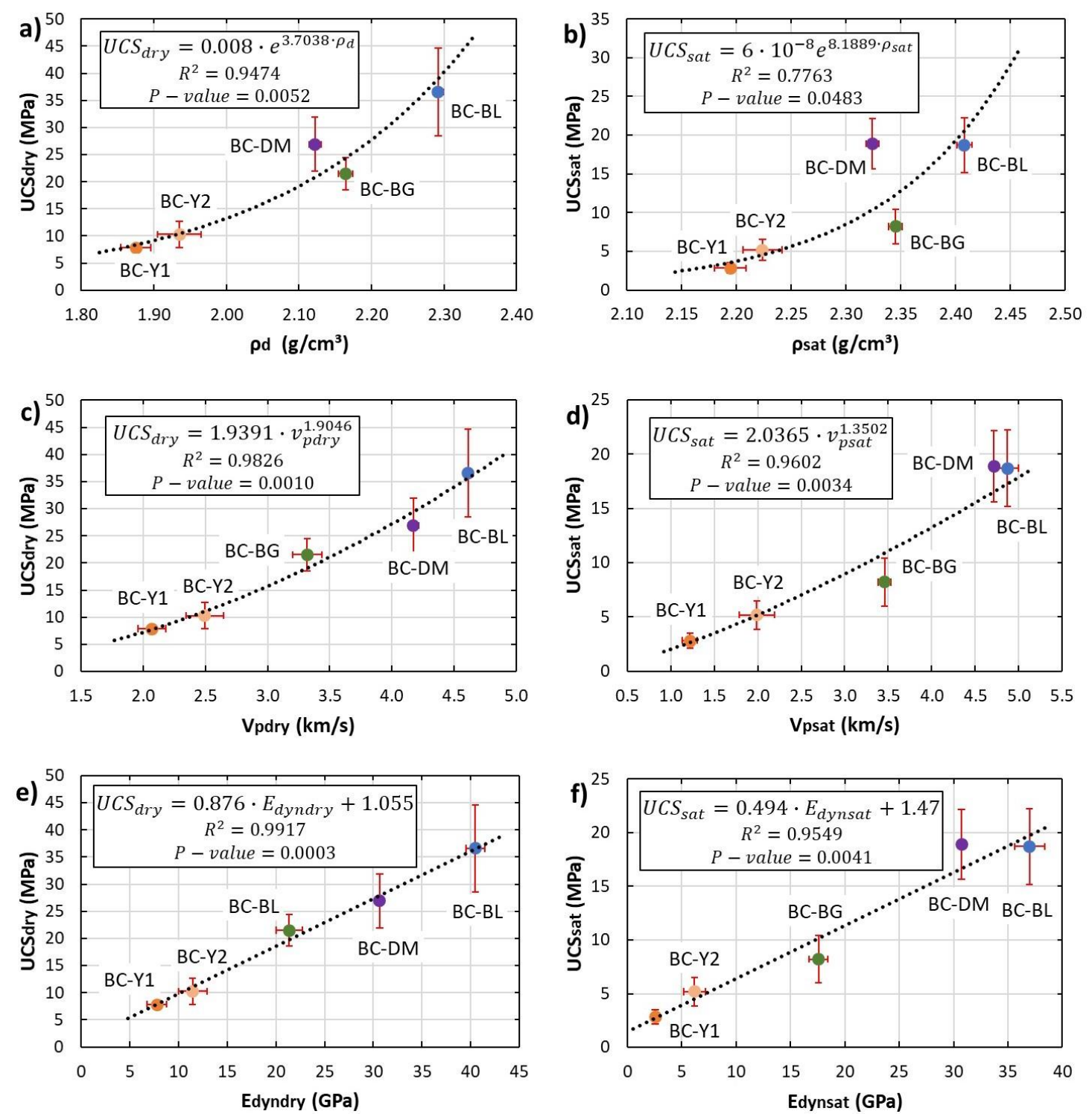

Fig. 8. Correlations between UCS and $\rho$ ( $a$ and b); UCS and $V_{p}$ (c and d); and UCS and $E_{\text {dyn }}(e$ and $f$ ) in dry and saturated samples, respectively. 


\subsubsection{Static elastic modulus loss. Correlations with physical and ultrasonic properties.}

The different $E_{\text {st }}$ loss obtained in each calcarenite variety followed a very similar pattern to UCS loss and can be attributed to the same reasons. In others words, the greater $E_{\text {st }}$ loss of yellow calcarenite might be a consequence of its lower intergranular cementation and its higher porosity and water absorption capacity. Therefore, with regards of Bateig calcarenites, the bigger $E_{s t}$ loss of Beige and Blue varieties compared to Diamond variety can be attributed to the greater presence of clay minerals in their composition that induce a higher deformability when undergo saturated.

In the same way as UCS, static Young's modulus in dry state $\left(\mathrm{E}_{\text {stdry }}\right)$ was plotted as a function of static Young's modulus in saturated state $\left(\mathrm{E}_{\mathrm{stsat}}\right)$ and the slope of the fitted line $\left(\mathrm{K}_{\mathrm{Est}}\right)$ obtained by least-square method was 0.568 , indicated a loss mean value of $43.2 \%$ due to water saturation. This finding is close to the previous results obtained in limestones by Vásárhelyi [10] and in British sandstones by Hawking and McConell [17]. However, the $E_{s t}$ loss obtained in calcarenites is substantially lower than the results obtained in several argillaceous Turkish rocks by Karakul and Ulusay [12] or Erguler and Ulusay [22] and slightly higher than the findings reported in sandstones by Kim et al [53] (Fig. 7.c).

Concerning relationships between $\mathrm{E}_{\text {st }}$ and physical properties, some fitting functions were tested (lineal, exponential, power, etc.) and the curve with the highest $R^{2}$ was chosen. In particular, exponential correlations between $E_{s t}$ and $V_{p}$ and lineal correlations between $E_{d y n}$ and $E_{s t}$ were obtained in dry and saturated states (Fig. 9). Based on this findings, non-destructive ultrasonic technique can be used to indirectly estimate the deformability of calcarenite stone structures not only in dry state as reported by Brotons et al. [23], but also in saturated rocks elements. This is an important aspect for maintenance or interventions in specific situations. Similar function types were found by others authors (Table 2).
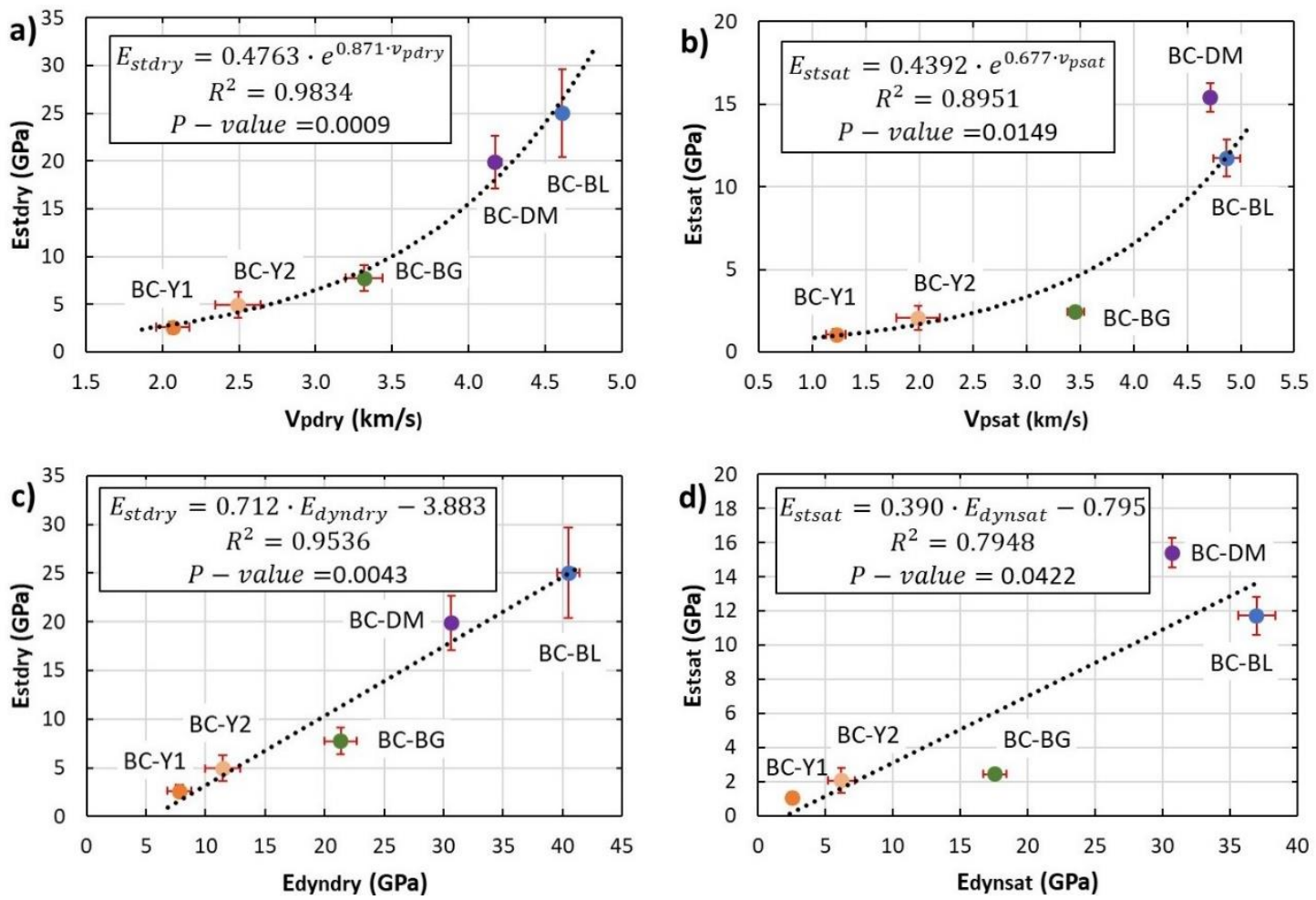

Fig. 9. Correlations between $E_{s t}$ and $V_{p}(a$ and $b)$; and $E_{s t}$ and $E_{d y n}(c$ and $d)$ in dry and saturated samples, respectively. 


\subsection{Point Load Strength Index loss. Correlations with physical and ultrasonic properties.}

The distinct $I_{s(50)}$ loss found for each calcarenite variety is consistent with the variations measured in the other mechanical properties and can be attributed to the same causes. Furthermore, the Point Load Strength Index values in saturated state $\left(I_{s(50) \text { sat }}\right)$ was plotted as a function of the Point Load Strength Index in dry state $\left(\mathrm{I}_{S(50) \text { dry }}\right)$ for calcarenites and a linear trend was found (Fig. 7.d). The slope of the best fitting line $\left(\mathrm{K}_{\mathrm{ls}(50)}\right)$ was 0.542 , suggesting a mean $\mathrm{I}_{\mathrm{s}(50)}$ loss of $45.8 \%$. This loss is smaller than that found in volcaniclastic rocks, including tuff dacite and tuffaceous mudstone, sandstone and conglomerate, studied by Kohno and Maeda [54] and higher than the value obtained in several Norwegian rock types characterized by Broch [18] . Similar findings were reported by Kahraman [19] in Turkish pyroclastic samples. The results of these studies are also plotted in Fig. 7.d.

Regarding the relationships between $\mathrm{I}_{s(50)}$ and physical properties, significant correlations (Pvalue $<0,05$ ) were obtained in dry and saturated conditions and those with the highest coefficient of determination were selected. Specifically, power best fitting functions were proposed between $I_{s(50)}$ and $\rho_{b}$ and between $I_{s(50)}$ and $V_{p}$. Similarly, exponential and lineal correlations were found between $I_{s(50)}$ and $p$ and $I_{s(50)}$ and $E_{d y n}$, respectively (Fig. 10). 

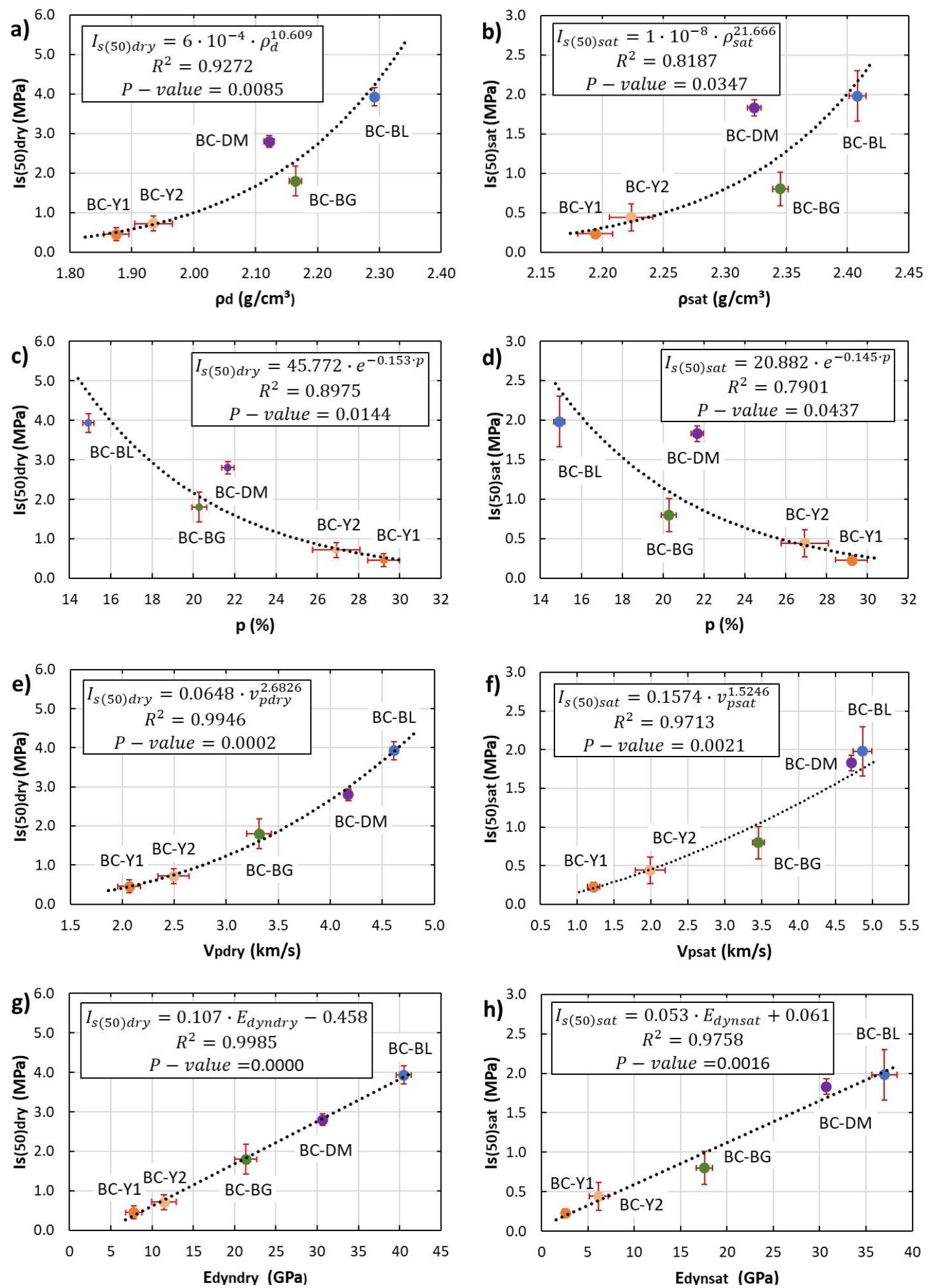

Fig. 10. Correlations between $I_{s(50)}$ and $\rho(a$ and $b) ; I_{s(50)}$ and $p(c$ and $d) ; I_{s(50)}$ and $V_{p}(e$ and $f)$; and $I_{s(50)}$ and $E_{d y n}(g$ and $h)$ in dry and saturated samples, respectively.

\subsection{Correlations between mechanical properties in dry and saturated conditions}

UCS is one of the most used rock mechanical properties because of their relevance in geotechnical applications. However, laboratory tests to obtain this parameter are generally relatively time-consuming, expensive and required well-prepared rock cores. $I_{s(50)}$ is an easy 
alternative to estimate the UCS for preliminary studies because of the simplicity for preparing the sample, the speed of test and the potential field application. Many investigations have found relationships between $I_{s(50)}$ and UCS [19] but, very few studies have been focused on soft rocks such calcarenites and the influence of water. In this paper, a lineal correlation between $I_{s(50)}$ and UCS was obtained for calcarenite stones in dry and saturated conditions and the $k$ factor value $\left(\mathrm{k}=\mathrm{UCS} / \mathrm{I}_{\mathrm{s}(50)}\right)$ varies between 9 and 10 . It is important to note that this $\mathrm{k}$ factor is notably less than those reported by ISRM [55] who established $k$ values between 15 and 50 for most of the rocks. This finding is consistent with the result obtained by others authors ([19], [56]-[59]), who suggested that k kactor is smaller in soft rocks (Fig. 11.a).

The possibility of estimating the elastic modulus of rocks through PLT has been poorly examined. In this study a significant lineal correlation functions between $\mathrm{I}_{\mathrm{s}(50)}$ and $\mathrm{E}_{\mathrm{st}}$ for dry and saturated calcarenites were established. Fig. 11.b shows the proposed correlations as well as a power function proposed by Daoud et al. [21] for Iraqi limestones and sandstones, as well as a lineal correlation inferred from the data obtained by Kurtulus et al. [32] for Turkish serpentinized rocks.
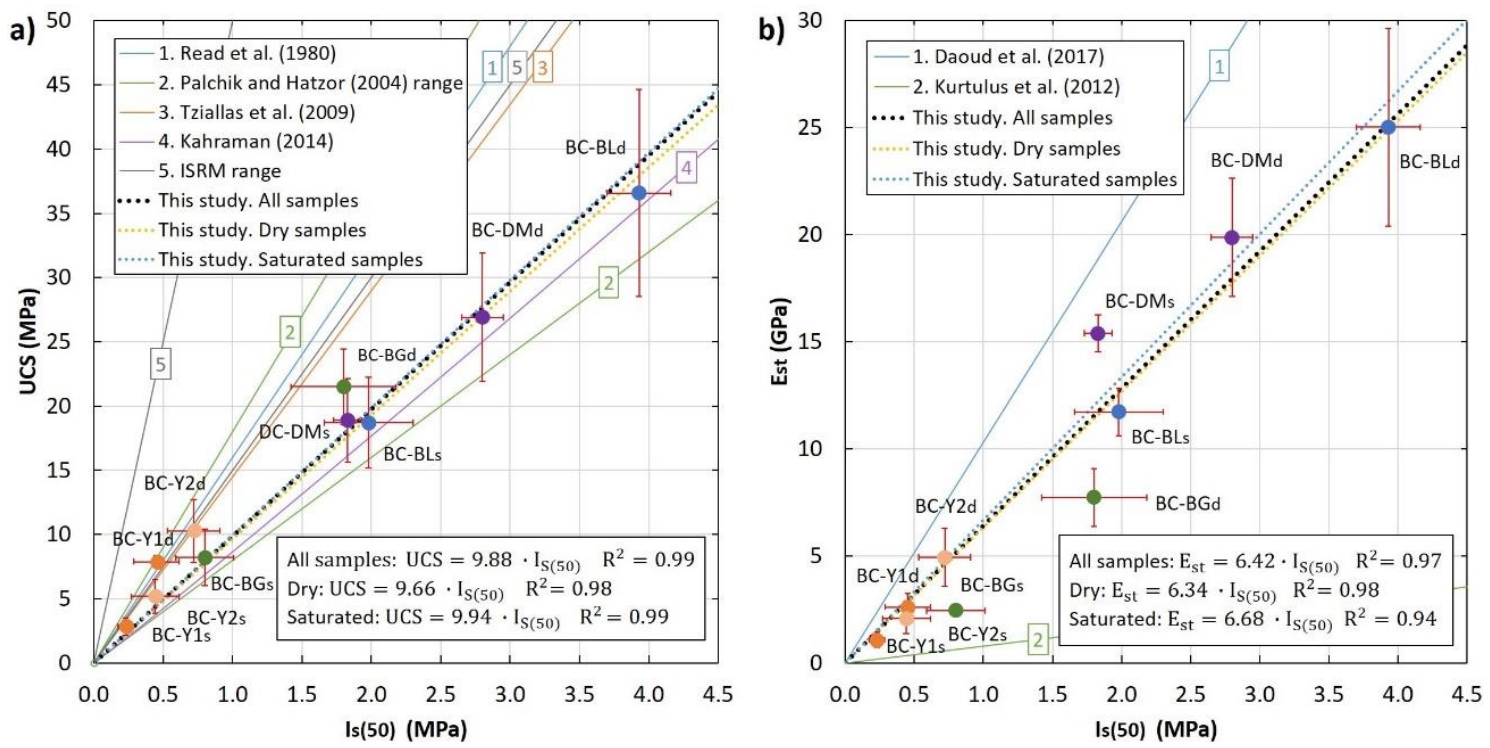

Fig. 11. Correlation between $\mathrm{I}_{s(50}$ and UCS (a) and between $\mathrm{I}_{s(50)}$ and $\mathrm{E}_{\mathrm{st}}$ in dry and saturated calcarenites and comparison with other functions published in scientific literature. $d$ and $s$ subscripts indicate dry and saturated conditions, respectively.

These derived correlation functions are very practical to obtain indirectly the strength and the deformability of soft calcarenites (like yellow varieties), in which to extract intact core samples to carry out UCS and $E_{s t}$ test is quite difficult.

Other parameter frequently used in rock mechanics is the ratio between the $E_{s t}$ and the UCS (modulus ratio) due to its usefulness in engineering practice for the determination of $E_{s t}$. In this regard, lineal correlations between these parameters were found in dry and saturated calcarenites. The slopes of the fitting lines are very similar in both saturation states and considerably higher than those reported in other sedimentary rocks by Vásárhelyi [10] (limestones), Sachpazis [60] (carbonate rocks) and Shalabi et al. [61] (dolomite and shale rocks). These findings suggested that the water content does not influence significantly on $\mathrm{E}_{\mathrm{st}} / \mathrm{UCS}$ value as reflected in Fig. 12. 


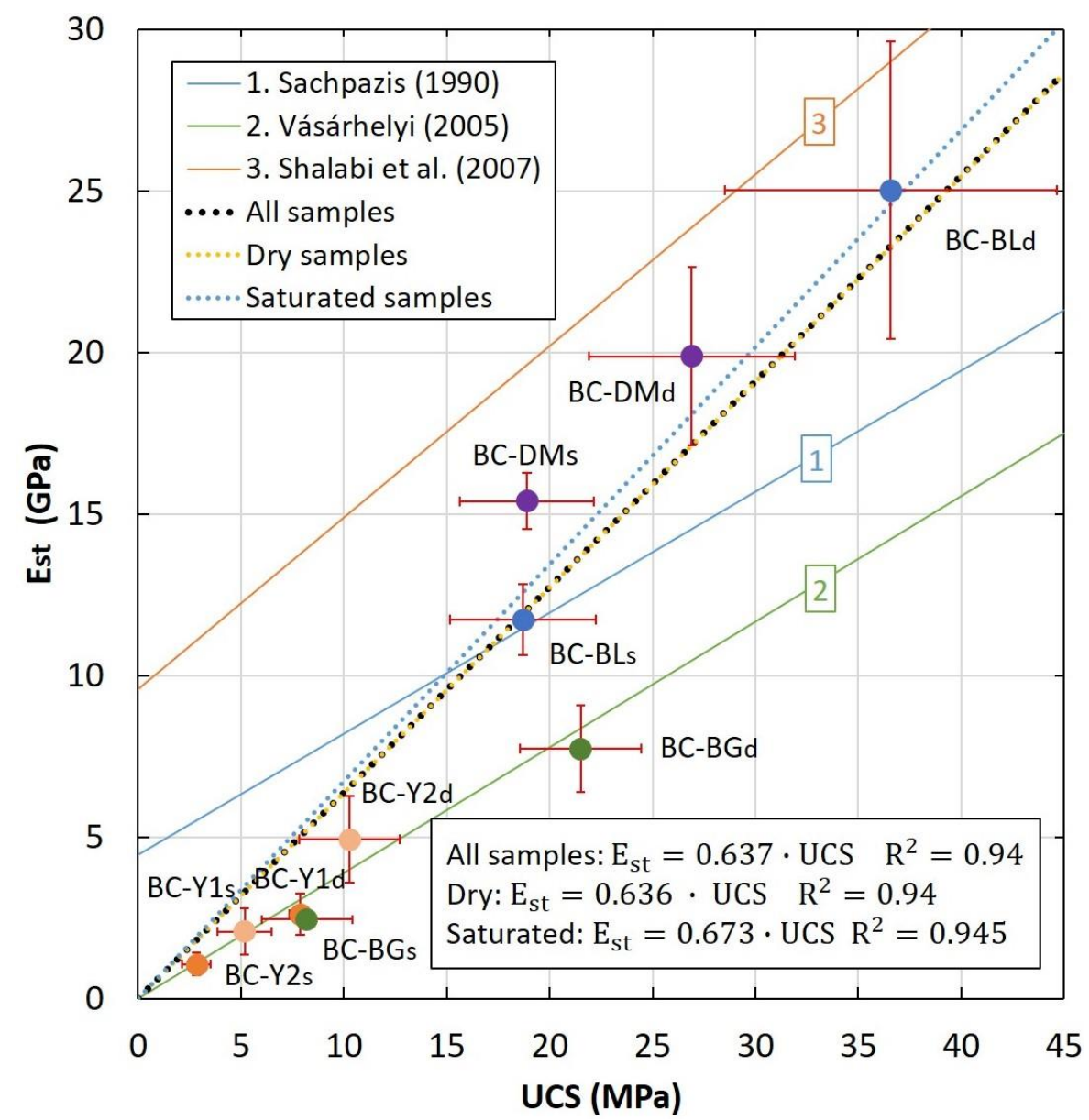

Fig. 12. Correlation between UCS and $E_{s t}$ in dry and saturated calcarenites and comparison with a compilation of functions published in scientific literature. $d$ and s subscripts indicate dry and saturated conditions, respectively.

\section{CONCLUSIONS}

The most important findings of this research are summarized as follows:

(1) Mechanical properties reduced by about one half on average after water saturation for the studied stones. In particular, the greatest UCS, $E_{s t}$ and $I_{s(50)}$ losses were measured in yellow (64, 59 and $49 \%$, respectively) and Beige (62, 68 and 56\%, respectively) calcarenites and could be attributed to their greater porosity, water absorption capacity, clay mineral content and lower intergranular cementation. Diamond calcarenite exhibited the smallest water sensitivity (UCS, $E_{s t}$ and $I_{s(50)}$ decreased by 30,23 and $35 \%$, respectively).

(2) Significant correlations between physical $\left(\rho_{b}, p, V_{p}\right.$ and $\left.E_{d y n}\right)$ and mechanical properties (UCS, $E_{s t}$ and $\left.I_{s(50)}\right)$ were found under dry and saturated conditions. These correlations enable the indirect prediction of the behaviour and durability of rock materials and optimise the selection of the most suitable rock variety at quarry level when it is expected that they were exposed to wet environments during its lifetime. In addition, based on this findings, non-destructive test like ultrasonic technique can be used to indirectly estimate mechanical properties in dry and also saturated calcarenite stone structures. This is a relevant aspect in specific situations like maintenance, prospecting, monitoring and interventions in monuments, heritage buildings or other constructions that can undergo saturated along their lifetime.

(3) Novel correlations functions between $I_{s(50)}$ and the most important mechanical properties (UCS and $\mathrm{E}_{\mathrm{st}}$ ) were also found in calcarenites under dry and saturated conditions. The derived 
functions provide an alternative way to the development of time-consuming and expensive mechanical laboratory tests for the indirect determination of UCS and $E_{s t}$.

\section{Acknowledgements}

This work was supported by the Vicerrectorado de Investigación y Transferencia del Conocimiento of the University of Alicante through Predoctoral grant FPUUA53-2018 and the projects UAUSTI18-21 and UAEEBB2018-09. The authors thank the company "Bateig Piedra Natural S.A" for providing some rock samples and pictures used in this work. The authors would also like to express their gratitude to the Earth Sciences Department from the University of Alicante for allowing them to perform the thin sections analysis on their laboratories.

\section{References}

[1] D. Benavente, M. A. G. del Cura, R. Fort, and S. Ordónez, "Durability estimation of porous building stones from pore structure and strength," Eng. Geol., vol. 74, no. 1-2, pp. 113-127, 2004

[2] A. Bernabéu, M. A. García del Cura, F. Mingarro, M. C. López de Azcona, S. Ordóñez, and R. Fort, "La Piedra de Novelda: una roca muy utilizada en el patrimonio arquitectónico," Mater. Construcción, vol. 52, no. 266, pp. 19-32, 2010.

[3] M. Romana and B. Vásárhelyi, "A discussion on the decrease of unconfined compressive strength between saturated and dry rock samples," Proc. 11th Congr. Int. Soc. rock Mech., vol. 1 , pp. 139-142, 2007.

[4] A. La Iglesia, M. A. García del Cura, S. Ordoñez, and A. Bernabéu, "Estudio de los filosilicatos de la 'Piedra Bateig' (Neógeno de la provincia de Alicante)," Geogaceta, vol. 23, pp. 79-82, 1998.

[5] N. J. Price, "The compressive strength of coal measure rocks," Colliery Eng., vol. 37, no. 437, pp. 283-292, 1960.

[6] R. L. Mann and I. Fatt, "Effect of pore fluids on the elastic properties of sandstone," Geophysics, vol. 25, no. 2, pp. 433-444, Apr. 1960.

[7] P. S. B. Colback and B. L. Wild, "The influence of moisture content on the compressive strength of rock," in Proceedings of the 3rd Canadian Rock Mechanics Symposium, 1965, pp. 65-83.

[8] A. Shakoor and E. H. Barefield, "Relationship between unconfined compressive strength and degree of saturation for selected sandstones," Environ. Eng. Geosci., vol. 15, no. 1, pp. 29-40, 2009.

[9] E. Verstrynge, R. Adriaens, J. Elsen, and K. Van Balen, "Multi-scale analysis on the influence of moisture on the mechanical behavior of ferruginous sandstone," Constr. Build. Mater., vol. 54, pp. 78-90, 2014.

[10] B. Vásárhelyi, "Statistical analysis of the influence of water content on the strength of the miocene limestone," Rock Mech. Rock Eng., vol. 38, no. 1, pp. 69-76, 2005.

[11] Á. Török and B. Vásárhelyi, "The influence of fabric and water content on selected rock mechanical parameters of travertine, examples from Hungary," Eng. Geol., vol. 115, no. 3-4, pp. 237-245, 2010.

[12] H. Karakul and R. Ulusay, "Empirical correlations for predicting strength properties of rocks from P-wave velocity under different degrees of saturation," Rock Mech. Rock Eng., vol. 46, no. 5, pp. 981-999, 2013.

[13] S. Kahraman, "The correlations between the saturated and dry P-wave velocity of rocks," Ultrasonics, vol. 46, no. 4, pp. 341-348, 2007. 
[14] V. Gajic, V. Matovic, N. Vasic, and D. Sreckovic-Batocanin, "Petrophysical and mechanical properties of the Struganik limestone (Vardar zone, Western Serbia)," Geol. Anal. Balk. poluostrva, no. 72, pp. 87-100, 2011.

[15] M. L. Lin, F. S. Jeng, L. S. Tsai, and T. H. Huang, "Wetting weakening of tertiary sandstonesmicroscopic mechanism," Environ. Geol., vol. 48, no. 2, pp. 265-275, 2005.

[16] E. Kim and H. Changani, "Effect of water saturation and loading rate on the mechanical properties of Red and Buff Sandstones," Int. J. Rock Mech. Min. Sci., vol. 88, pp. 23-28, 2016.

[17] A. B. Hawkins and B. J. McConnell, "Sensitivity of sandstone strength and deformability to changes in moisture content," Q. J. Eng. Geol. Hydrogeol., vol. 25, no. 2, pp. 115-130, 1992.

[18] E. Broch, "Estimation of strength anisotropy using the point-load test," Int. J. Rock Mech. Min. Sci., vol. 20, no. 4, pp. 181-187, 1983.

[19] S. Kahraman, "The determination of uniaxial compressive strength from point load strength for pyroclastic rocks," Eng. Geol., vol. 170, pp. 33-42, 2014.

[20] X. Shi, W. Cai, Y. Meng, G. Li, K. Wen, and Y. Zhang, "Weakening laws of rock uniaxial compressive strength with consideration of water content and rock porosity," Arab. J. Geosci., vol. 9, no. 5, pp. 1-7, 2016.

[21] H. S. D. Daoud, K. A. R. Rashed, and Y. M. A. Alshkane, "Correlations of Uniaxial Compressive Strength and Modulus of Elasticity with Point Load Strength Index, Pulse Velocity and Dry Density of Limestone and Sandstone Rocks in Sulaimani Governorate, Kurdistan Region, Iraq," J. Zankoy Sulaimani - Part A- (Pure Appl. Sci., vol. 19, no. 3\&4, pp. 57-72, 2017.

[22] Z. A. Erguler and R. Ulusay, "Water-induced variations in mechanical properties of clay-bearing rocks," Int. J. Rock Mech. Min. Sci., vol. 46, no. 2, pp. 355-370, 2009.

[23] V. Brotons et al., "Improved correlation between the static and dynamic elastic modulus of different types of rocks," Mater. Struct. Constr., vol. 49, no. 8, pp. 3021-3037, 2016.

[24] P. Horsrud, "Estimating Mechanical Properties of Shale From Empirical Correlations," SPE Drill. Complet., vol. 16, no. 02, pp. 68-73, 2001.

[25] A. R. Najibi, M. Ghafoori, G. R. Lashkaripour, and M. R. Asef, "Empirical relations between strength and static and dynamic elastic properties of Asmari and Sarvak limestones, two main oil reservoirs in Iran," J. Pet. Sci. Eng., vol. 126, pp. 78-82, 2015.

[26] E. A. Eissa and A. Kazi, "Relation between static and dynamic Young's moduli of rocks," Int. J. Rock Mech. Min. Sci., vol. 25, no. 6, pp. 479-482, 1988.

[27] B. Christaras, F. Auger, and E. Mosse, "Determination of the moduli of elasticity of rocks. Comparison of the ultrasonic velocity and mechanical resonance frequency methods with direct static methods," Mater. Struct., vol. 27, no. 4, pp. 222-228, 1994.

[28] V. Brotons, R. Tomás, S. Ivorra, and A. Grediaga, "Relationship between static and dynamic elastic modulus of calcarenite heated at different temperatures: The San Julián's stone," Bull. Eng. Geol. Environ., vol. 73, no. 3, pp. 791-799, 2014.

[29] H. Awang, N. R. Ahmad Rashidi, M. Yusof, and K. Mohammad, "Correlation Between P-wave Velocity and Strength Index for Shale to Predict Uniaxial Compressive Strength Value," MATEC Web Conf., vol. 103, no. 07017, pp. 1-8, 2017.

[30] A. Jamshidi, M. R. Nikudel, M. Khamehchiyan, R. Zarei Sahamieh, and Y. Abdi, “A correlation between P-wave velocity and Schmidt hardness with mechanical properties of travertine building stones," Arab. J. Geosci., vol. 9, no. 568, pp. 1-12, 2016.

[31] C. Kurtuluş, T. S. Irmak, and I. Sertçelik, "Physical and mechanical properties of Gokceada: Imbros (NE Aegean Sea) island andesites," Bull. Eng. Geol. Environ., vol. 69, no. 2, pp. 321-324, 2010. 
[32] C. Kurtulus, A. Bozkurt, and H. Endes, "Physical and mechanical properties of Serpentinized ultrabasic rocks in NW Turkey," Pure Appl. Geophys., vol. 169, no. 7, pp. 1205-1215, 2012.

[33] AENOR, "UNE-EN 14579. Método de ensayo para piedra natural. Determinación de la velocidad de propagación del sonido.," Asoc. Española Norm. y Certificación, Madrid., 2005.

[34] AENOR, “UNE 22-950-90-1. Propiedades mecánicas de las rocas. Ensayos para la determinación de la resistencia. Parte 1: Resistencia a la compresión uniaxial.," Asoc. Española Norm. y Certificación, Madrid., pp. 1-4, 1990.

[35] AENOR, “UNE 22-950-90-3. Propiedades mecánicas de las rocas. Ensayos para la determinación de la resistencia. Parte 3: Determinación del módulo de elasticidad (Young) y del coeficiente de Poisson.," Asoc. Española Norm. y Certificación, Madrid., 1990.

[36] AENOR, “UNE 22950-5. Propiedades mecánicas de las rocas. Ensayos para determinación de la resistencia. Parte 5: Resistencia a carga puntual.," Asoc. Española Norm. y Certificación, Madrid. 1996.

[37] AENOR, "UNE 103-200-93. Determinación del contenido de carbonatos en los suelos," Asoc. Española Norm. y Certificación, Madrid., 1993.

[38] A. E1621-13, "Standard Guide for Elemental Analysis by Wavelength Dispersive X-Ray Fluorescence Spectrometry," in ASTM International, West Conshohocken, 2013.

[39] AENOR, “UNE-EN 1936. Métodos de ensayo para piedra natural. Determinación de la densidad real y aparente y de la porosidad abierta y total.," Asoc. Española Norm. y Certificación, Madrid., 2007.

[40] AENOR, "UNE 103-302-94. Determinación de la densidad relativa de las partículas de un suelo.," Asoc. Española Norm. y Certificación, Madrid., p. 4, 1994.

[41] S. Ordoñez, M. Louis, M. A. García del Cura, R. Fort, M. C. López de Azcona, and F. Mingarro, "Physical properties and petrographic characteristics of some Bateig stone varieties," in 7th International IAEG Congress, 1994, pp. 3595-3603.

[42] R. J. Dunham, "Classification of Carbonate Rocks According to Depositional Textures," Mem Am Assoc Pet Geol, vol. 1, pp. 108-121, 1962.

[43] W. Si, B. Di, J. Wei, and Q. Li, "Experimental study of water saturation effect on acoustic velocity of sandstones," J. Nat. Gas Sci. Eng., vol. 33, pp. 37-43, 2016.

[44] J. M. Kate, "Influence of Saturation on Dynamic Elastic Constants of Sandstones," in Rock Engineering and Technology for Sustainable Underground Construction Eurock 2012-the ISRM International Symposium, 2012, no. 1, pp. 1-9.

[45] A.R. Gregory, "Fluid saturation effects on dynamic elastic properties of sedimentary rocks," vol. 41, no. 5, pp. 895-921, 1976.

[46] G. Ballivy and J. C. Colin, "Stockage souterrain: Influence de la nature du fluide sur les propriétés mécaniques de la roche en paroi," in 9th Int. Cong. on Rock Mech., 1999, pp. 563-567.

[47] B. Vasarhelyi and K. Ledniczky, "Influence of water-saturation and weathering on mechanical properties of Sivac marble," in 9th Int. Cong. on Rock Mech., 1999, pp. 691-693.

[48] M. Tiennot, J. D. Mertz, and A. Bourgès, "Influence of Clay Minerals Nature on the Hydromechanical and Fracture Behaviour of Stones," Rock Mech. Rock Eng., vol. 52, no. 6, pp. 1599-1611, 2019.

[49] Á. Török, "Influence of fabric on the physical properties of limestones," in Fracture and Failure of Natural Building Stones, 2006, pp. 487-495.

[50] Z. Pápay and Á. Török, “Micro-Fabric, Pore-Size Distribution and Water Absorption of Consolidated Porous Limestone," Eng. Geol. Soc. Territ., vol. 8, pp. 553-556, 2015. 
[51] Á. Török and B. Szemerey-Kiss, "Freeze-thaw durability of repair mortars and porous limestone: compatibility issues," Prog. Earth Planet. Sci., vol. 6, no. 1, 2019.

[52] B. Szemerey-Kiss and Á. Török, "Porosity and compatibility of repair mortars and Hungarian porous limestones," Cent. Eur. Geol., vol. 55, no. 2, pp. 123-134, 2012.

[53] E. Kim and H. Changani, "Effect of water saturation and loading rate on the mechanical properties of Red and Buff Sandstones," Int. J. Rock Mech. Min. Sci., vol. 88, pp. 23-28, 2016.

[54] M. Kohno and H. Maeda, "Relationship between point load strength and uniaxial compressive strength of hydrothermally altered soft rocks," Int. J. Rock Mech. Min. Sci., vol. 50, pp. 147-157, 2012.

[55] J. A. Franklin, "Suggested method for determining point load strength," International Journal of Rock Mechanics and Mining Sciences and, vol. 22, no. 2. pp. 51-60, 1985.

[56] V. Palchik and Y. H. Hatzor, "The Influence of Porosity on Tensile and Compressive Strength of Porous Chalks," Rock Mech. Rock Eng., vol. 37, no. 4, pp. 331-341, 2004.

[57] J. R. L. Read, P. N. Thornten, and W.M. Regan, "A rational approach to the point load test," in 3rd Australian-New Zealand Geomechanics Conference, 1980, pp. 35-39.

[58] G. P. Tziallas, G. Tsiambaos, and H. Saroglou, "Determination of rock strength and deformability of intact rocks," Electron. J. Geotech. Eng., vol. 14, pp. 1-12, 2009.

[59] J. Rusnak and C. Mark., "Using the point load test to determine the uniaxial compressive strength of coal measure rock," in Proceedings of the 19th International Conference on Ground Control in Mining., 2000, pp. 362-371.

[60] C. I. Sachpazis, "Correlating schmidt hardness with compressive strength and young's modulus of carbonate rocksCorrélations entre la dureté au marteau schmidt et la résistance à la compression simple et à la déformation (module young) de roches carbonatées," Bull. Int. Assoc. Eng. Geol., vol. 42, no. 1, pp. 75-83, 1990.

[61] F. I. Shalabi, E. J. Cording, and O. H. Al-Hattamleh, "Estimation of rock engineering properties using hardness tests," Eng. Geol., vol. 90, no. 3-4, pp. 138-147, 2007. 